\title{
Diseases of Tropical Perennial Crops: Challenging Problems in Diverse Environments
}

The world's oldest ecosystems are found in the tropics. They are diverse, highly evolved, but barely understood. Diseases that impact crops in these regions can be significant contraints to production, especially when they occur in lowland environments with high rainfall and uniform, warm temperatures; respites from disease pressure there are often infrequent. Difficulties in managing diseases in the humid tropics are multiplied when the affected crops are perennial. The favorable conditions for disease development and the presence of susceptible host tissue over long periods make diseases of tropical perennial crops serious management challenges.

This topic is introduced with a few concepts on the occurrence and development of these pathosystems. Peculiar aspects and scenarios that influence the types of and extent to which different diseases develop are summarized. Measures that are useful on annual or short-term crops may be ineffective against these diseases. They are scientifically interesting problems. New vectors, as for mango malformation, or pathogens, as for bunchy top of papaya, are associated with some of the diseases. And some of the diseases are caused by two or more distinct taxa; for example, citrus greening, mango malformation, Panama disease, and tracheomycosis of coffee. Some of the most important diseases are host-specific and are caused by either coevolved or new-encounter pathogens. Resistance, the most effective tool with which many of these diseases are managed, is usually available in coevolved pathosystems but may be uncommon in new-encounter situations. Inadequate host resistance can be a significant barrier in the management of both coevolved and new encounter diseases.

General tactics are described that are useful against diseases of tropical perennials. The successful management of plant disease utilizes several principles and

Corresponding author: R. C. Ploetz, University of Florida, Department of Plant Pathology, Tropical Research and Education Center, 18905 S.W. 280th Street, Homestead, FL 33031-3314, USA; E-mail: rcp@ifas.ufl.edu

doi:10.1094/PDIS-91-6-0644

(C) 2007 The American Phytopathological Society practices, regardless of the host and environment in which it is grown. These include the avoidance, exclusion, and eradication of the causal agents. Host protection is of great importance, as is the identification and incorporation of resistance in the host plant. All of these approaches are discussed with tropical perennial examples.

\section{Agriculture Begins}

Agriculture began after the Pleistocene (last ice age) and started independently in several different regions (Table 1). It developed first in the Near East (sites in the Fertile Crescent and in present-day Israel and Turkey) due to a fortuitous combination of suitable climate and useful plants and animals that could be domesticated $(33,76,144)$. These first farmers appeared at least 11,000 years ago, and were followed in quick succession by others in Northern and Southern China, Mesoamerica, New Guinea, the Andes, and the Eastern United States (32-34). Additional areas of independent development may also include Amazonia, Ethiopia, the Sahel, Southeast Asia, and Western Africa.

During agriculture's brief history, humans have utilized numerous plants $(12,21,91,135,148)$. At least 3,000 taxa have been used for food and several hundred more have been used for other purposes. In Table 2, the following categories have been considered: beverage, drug, elastomer, fiber, food, insecticide, oil, spice, and timber and pulp.

Despite the large numbers of useful species, only a subset is very significant and few are of major importance $(114,128,136$, 143,148). Scarcely more than a hundred species enter world commerce, and among the food crops, few are staples: About $0.5 \%$ of the food species supply more than $90 \%$ of the world's food $(42,148)$.

\section{Biological Diversity in the Tropics}

Biological diversity increases with decreasing latitude $(61,67,162)$. This trend, called the Latitudinal Diversity Gradient (LDG), has been observed for a wide range of trophic levels and life forms. In general, species numbers increase dramatically as one moves from the poles to the equator.

The LDG is one of the oldest recognized patterns in the biological sciences. Hum- boldt (63) discussed the relationship two centuries ago, and Darwin (26) wrote about it in his famous book. This increase in diversity is most pronounced in tropical rain forests, which are thought to host $50 \%$ of all species but occupy only $7 \%$ of the world's landmass (162). And it appears to be a general rule on our planet since it is found in the fossil record and re-establishes after mass extinctions (67).

Plants are among the most prominent organisms that conform to the LDG. Thus, it is not surprising that most of the early agricultural hubs (nine of the above 12) and first crop domestications occurred in the tropics, i.e., between the Tropics of Cancer and Capricorn (Table 1). More than half the crops in Table 2, 69 of 126 (55\%), originated in the tropics. Some tropical annuals, e.g., rice, potato, and maize, are now also grown in temperate zones during the summer. But essentially all tropical perennials are restricted to the tropics due to their cold sensitivity.

A wide range of habitats is found in the tropics, including humid lowlands, deserts, seasonally dry forests, grasslands, savannahs, montane environments, and swamps $(148,161)$. Further diversity in each of these habitats results from variable edaphic, meterologic, and biotic conditions. This vast array of environments enables an equally wide range of plants to be grown; almost every crop in Table 2 can be grown somewhere in the tropical world. For example, important temperate domesticates are grown in the lowland tropics (members of the Brassicaceae and Fabaceae are especially common) and at high elevations where moderate temperatures exist (members of the Fabaceae, Poaceae, and Rosaceae are most notable) (114). Thurston's (148) estimate that twice as many crops are grown in the tropics as in the temperate zones of the world is probably accurate.

Studies that compare tropical and temperate ecosystems are uncommon, and a disproportionate amount of the research on microorganisms has been conducted in temperate zones. For example, in reviewing the literature on fungi and bacteria in forest ecosystems since 1963, Lodge et al. (87) found only 96 references for tropical forests, but 2,411 for temperate forests. Despite this disparity, the LDG is also evident among microbes. 
Three groups of nonpathogenic fungi, decomposers (86), endophytes (6), and arbuscular mycorrhizae (64), are very diverse in the tropics, as are fungi in general $(156,157)$. Plant pathogens also appear to be more numerous and diverse in the tropics. One group, the flagellated protozoa (Phytomonas spp.), is rare outside the tropics (2), and $60 \%$ of the described viroid species have tropical, natural hosts (55).

If one considers diseases of crop plants, there may be an even greater difference between temperate and tropical areas. Wellman (161) found a pronounced temperate/tropical bias among the crops that were well represented in both zones: pumpkin and squash, 19 temperate diseases and 111 tropical; sweet potato, 15/187; tomato, 32/278; common bean, 52/253+; and potato, 91/175. Wellman (159-161) concluded that for every disease that occurred on a given crop in temperate areas there were 10 in the tropics.

Disease problems can be severe in the tropics, especially where high rainfall and uniform, warm temperatures are the norm. These conditions are highly favorable for the development of most diseases, and respites from disease pressure are usually infrequent in these areas. Overall, losses are thought to be 50 to $100 \%$ higher in tropical than in temperate regions $(60,148)$. Estimates of the proportion of all losses in the tropics that are caused by diseases range from $30 \%$ (56) to $50 \%$ (161).

Plant pathology began in, and generally continues to be a discipline focused on, temperate climates; comparatively little plant pathological research has been conducted in the developing tropical world (143). Work in the tropics has made significant contributions to the discipline of plant pathology $(100,132)$, but much more would be revealed if resources that approached those used in temperate zones were devoted to research in the tropics.

Perennial crops: Challenging hosts for disease managers. When one considers the total areas planted and annual yields, the most important food crops are annuals. Other than sugarcane (its total represents harvested cane, not a final product), only production figures for maize, rice, and wheat exceed 500 million metric tons per year (Table 2). Although they are minor components of most natural floras, annuals predominate in agriculture for the following reasons: they produce quick results after planting; when stored, they enable escape from unfavorable climatic conditions (particularly the grains and pulses); and when incorporated in fallow or rotation cultures, they facilitate the avoidance of pests and pathogens (128).

Despite the importance of annual crops, Table 2 indicates that perennial crop plants (those that live longer than 2 years [4]) are more numerous (73 of the 126 [58\%]). There are several reasons why these most common hosts are often serious disease management challenges.

Rather than being protected for a few weeks or months, perennial hosts require long-term measures. Since they are longlived and there are no seasonal breaks in production, perennials are more prone to inoculum buildup and epidemic disease development.

Managing the large reservoirs of inoculum and high disease pressures that develop in perennial monocultures can be difficult and costly. For example, management of black Sigatoka leaf spot of banana (black leaf streak), caused by Mycosphaerella fijiensis, contributes as much as $25 \%$ of the final retail cost of export bananas and can fail during periods of high rainfall or less than adequate fungicide applications (105). In India, 10\% of the total costs of coffee production went toward the control of rust (130). And eradication efforts can be very expensive. Cacao swollen shoot, caused by Cacao swollen shoot virus, in West Africa and citrus canker, caused by Xanthomonas axonopodis pv. citri, in Florida are worst-case examples of where large sums of money were invested in ultimately unsuccessful campaigns.

Due to long-term selection pressure, there are increased opportunities in perennial systems for the development of pesticide-resistant pathogens. Despite an increased awareness of pesticide resistance and the establishment of strategies to avoid the build-up of resistant strains (11), a rapid erosion of the efficacy of new chemicals is still common $(68,120)$.

Long-term exposure to disease-promoting or predisposing factors can increase disease development in perennial hosts (7). Host nutritional status is an important abiotic factor that can be related to increased disease $(27,101)$. Likewise, an excess of water can encourage the development of diseases induced by stramenopiles

Table 1. Crop plants that were domesticated in early agricultural centers ${ }^{\mathrm{Z}}$

\begin{tabular}{|c|c|c|c|c|c|c|c|}
\hline \multirow[b]{2}{*}{ Area } & \multirow[b]{2}{*}{$\begin{array}{l}\text { First dates } \\
\text { (years B.P.) }\end{array}$} & \multicolumn{6}{|c|}{ Crops } \\
\hline & & $\begin{array}{l}\text { Grasses and } \\
\text { grains }\end{array}$ & Pulses & Fiber & $\begin{array}{l}\text { Root and } \\
\text { tubers }\end{array}$ & $\begin{array}{l}\text { Melons and } \\
\text { squash }\end{array}$ & $\begin{array}{l}\text { Fruit and } \\
\text { vegetables }\end{array}$ \\
\hline Fertile Crescent & 11,500 & $\begin{array}{l}\text { Emmer and } \\
\text { einkorn wheat, } \\
\text { barley }\end{array}$ & $\begin{array}{c}\text { Pea, lentil, } \\
\text { chickpea }\end{array}$ & Flax & None & Muskmelon & Date, fig \\
\hline China & 10,000 & $\begin{array}{l}\text { Rice, foxtail and } \\
\text { broomcorn } \\
\text { millet }\end{array}$ & $\begin{array}{l}\text { Soybean, adzuki } \\
\text { bean, mung } \\
\text { bean }\end{array}$ & Hemp & None & None & None \\
\hline MesoAmerica & 10,000 & Maize & $\begin{array}{l}\text { Common bean, } \\
\text { tepary bean, } \\
\text { scarlet runner } \\
\text { bean }\end{array}$ & $\begin{array}{l}\text { Cotton } \\
\text { (G. hirsutum), } \\
\text { Yucca spp. } \\
\text { Agave spp. }\end{array}$ & Jicama & $\begin{array}{l}\text { Squashes } \\
\text { (C. pepo, etc.) }\end{array}$ & $\begin{array}{l}\text { Pepper (Capsicum } \\
\text { spp.), avocado }\end{array}$ \\
\hline $\begin{array}{l}\text { Andes, } \\
\text { Amazonia }\end{array}$ & $3,500-1,000$ & Quinoa & $\begin{array}{l}\text { Lima bean, } \\
\text { common bean, } \\
\text { peanut }\end{array}$ & $\begin{array}{l}\text { Cotton }(G . \\
\text { barbadense })\end{array}$ & $\begin{array}{l}\text { Cassava, sweet } \\
\text { potato, potato, } \\
\text { oca }\end{array}$ & $\begin{array}{l}\text { Squashes }(C . \\
\text { maxima, etc.) }\end{array}$ & Pineapple \\
\hline $\begin{array}{l}\text { West Africa and } \\
\text { Sahel }\end{array}$ & $\begin{array}{l}3,000 \text { and } \\
5,000\end{array}$ & $\begin{array}{l}\text { Sorghum, pearl } \\
\text { millet, African } \\
\text { rice }\end{array}$ & $\begin{array}{l}\text { Cowpea, } \\
\text { groundnut }\end{array}$ & $\begin{array}{l}\text { Cotton }(G . \\
\text { herbaceum })\end{array}$ & Yams & $\begin{array}{l}\text { White-flowered } \\
\text { (bottle) gourd }\end{array}$ & Watermelon \\
\hline India & 5,000 & None & $\begin{array}{l}\text { Hyacinth bean, } \\
\text { black gram, } \\
\text { green gram }\end{array}$ & $\begin{array}{l}\text { Cotton } \\
\text { (G. arboreum), } \\
\text { flax }\end{array}$ & & Cucumber & Mango \\
\hline Ethiopia & 3,000 & Teff, finger millet & None & None & None & None & None \\
\hline Eastern USA & $2,500-1,000$ & $\begin{array}{l}\text { Maygrass little } \\
\text { barley, knotweed, } \\
\text { goosefoot }\end{array}$ & & & $\begin{array}{l}\text { Jerusalem } \\
\text { artichoke }\end{array}$ & Squash (C. pepo) & \\
\hline New Guinea & 7,000 & Sugarcane & None & None & None & None & Banana \\
\hline
\end{tabular}

${ }_{\mathrm{z}}$ Adapted from refs. 33 and 136; additional data are from 32, 34, 76, and 128. 
Table 2. Taxonomy, origins, and production zones of the major crop plants ${ }^{\mathrm{u}}$

\begin{tabular}{|c|c|c|c|c|c|c|c|}
\hline & Order & $\begin{array}{l}\text { Family } \\
\text { (subfamily) }\end{array}$ & Crop(s), taxa & $\begin{array}{l}\text { Category/ } \\
\text { usage }\end{array}$ & $\begin{array}{l}\text { Center } \\
\text { of origin }\end{array}$ & $\begin{array}{l}\text { Major production } \\
\text { areas }\end{array}$ & $\begin{array}{l}\text { Production, } \\
2005(t)\end{array}$ \\
\hline \multicolumn{8}{|l|}{ Gymnosperms } \\
\hline & Coniferales & Pinaceae & Pines, Pinus spp. & Timber, pulp & Diverse & \multicolumn{2}{|c|}{ Temperate to tropical N.A. } \\
\hline & & & Spruces, Picea spp. & Timber, pulp & $\begin{array}{l}\text { Northern } \\
\text { Hemisphere }\end{array}$ & Temperate & N.A. \\
\hline & & & Larches, Larix spp. & Timber, pulp & $\begin{array}{l}\text { Northern } \\
\text { Hemisphere }\end{array}$ & Temperate & N.A. \\
\hline & & & $\begin{array}{l}\text { Douglas firs, } \\
\text { Pseudotsuga spp. }\end{array}$ & Timber, pulp & $\begin{array}{l}\text { Northern } \\
\text { Hemisphere }\end{array}$ & Temperate & N.A. \\
\hline Angiosperms & & & Spruces, Picea spp. & Timber, pulp & $\begin{array}{l}\text { Northern } \\
\text { Hemisphere }\end{array}$ & Temperate & N.A. \\
\hline \multirow[t]{4}{*}{$\begin{array}{l}\text { Magnoliid } \\
\text { complex }\end{array}$} & \multirow[t]{3}{*}{ Laurales } & Myristicaceae & $\begin{array}{l}\text { Nutmeg, mace, } \\
\text { Myristica fragrans }\end{array}$ & Spice & Moluccas & $\begin{array}{l}\text { Indonesia, Grenada, } \\
\text { Sri Lanka, India } \\
\text { Malaysia }\end{array}$ & 81,292 \\
\hline & & \multirow[t]{2}{*}{ Lauraceae } & $\begin{array}{l}\text { Avocado, } \\
\text { Persea americana }\end{array}$ & Fruit & $\begin{array}{l}\text { Tropical } \\
\text { America }\end{array}$ & $\begin{array}{l}\text { Mexico, USA, } \\
\text { Indonesia, South } \\
\text { Africa, Chile }\end{array}$ & $3,229,134$ \\
\hline & & & $\begin{array}{l}\text { Cinnamon, } \\
\text { Cinnamomum }_{\text {verum }^{\mathrm{w}}}\end{array}$ & Spice & Sri Lanka & $\begin{array}{l}\text { Indonesia, Sri Lanka, } \\
\text { India, Seychelles, } \\
\text { Madagascar }\end{array}$ & 134,410 \\
\hline & Piperales & Piperaceae & $\begin{array}{l}\text { Black pepper, } \\
\text { Piper nigrum }\end{array}$ & Spice & Southwest India & $\begin{array}{l}\text { India, Indonesia, } \\
\text { Brazil }\end{array}$ & 411,359 \\
\hline \multirow[t]{18}{*}{ Monocots } & \multirow[t]{2}{*}{ Alistamatales } & \multirow[t]{2}{*}{ Araceae } & $\begin{array}{l}\text { Taro, Colocasia } \\
\text { esculenta }\end{array}$ & $\begin{array}{l}\text { Root and } \\
\text { tuber }\end{array}$ & Indo-Malaya & West Africa, Pacific & $10,586,651$ \\
\hline & & & $\begin{array}{l}\text { Yautia (tanier), } \\
\text { Xanthosoma } \\
\text { sagittifolium }\end{array}$ & $\begin{array}{l}\text { Root and } \\
\text { tuber }\end{array}$ & $\begin{array}{l}\text { Tropical } \\
\text { America }\end{array}$ & $\begin{array}{l}\text { Caribbean, West } \\
\text { Africa, Pacific }\end{array}$ & 421,966 \\
\hline & \multirow[t]{4}{*}{ Asparagales } & Orchidaceae & $\begin{array}{l}\text { Vanilla, } \\
\text { Vanilla planifolia }\end{array}$ & Spice & $\begin{array}{l}\text { SE Mexico, } \\
\text { C. America }\end{array}$ & $\begin{array}{l}\text { Madagascar, } \\
\text { Indonesia, China }\end{array}$ & 10,539 \\
\hline & & Alliaceae & \multirow{2}{*}{$\begin{array}{l}\text { Garlic, onion, } \\
\text { Allium spp. } \\
\text { Agave fibers, } \\
\text { Agave spp. (mainly } \\
\text { sisal, A. sisalana) }\end{array}$} & Spice & Near East & USA, Japan, Spain & $\begin{array}{l}14,548,669 \\
57,400,277\end{array}$ \\
\hline & & Agavaceae & & Fiber & $\begin{array}{l}\text { MesoAmerica, } \\
\text { Caribbean }\end{array}$ & Brazil, East Africa & 385,463 \\
\hline & & Asparagaceae & Asparagus & Vegetable & & & $6,658,007$ \\
\hline & \multirow[t]{5}{*}{ Dioscoreales } & Dioscoreaceae & Yams, Dioscorea spp. & $\begin{array}{l}\text { Root and } \\
\text { tuber }\end{array}$ & $\begin{array}{l}\text { Asia, Africa, } \\
\text { Tropical } \\
\text { America }\end{array}$ & \multirow{2}{*}{$\begin{array}{l}\text { West Africa, } \\
\text { Southeast Asia, } \\
\text { Oceania, Caribbean } \\
\text { Southeast Asia }\end{array}$} & $39,856,954$ \\
\hline & & $\begin{array}{r}\text { Arecaceae } \\
\text { (Palmae) }\end{array}$ & $\begin{array}{l}\text { Betel nut, } \\
\text { Areca catechu }\end{array}$ & $\begin{array}{l}\text { Drug- } \\
\text { medicinal }\end{array}$ & Southeast Asia & & 727,425 \\
\hline & & & $\begin{array}{l}\text { Coconut, } \\
\text { Cocos nucifera }\end{array}$ & $\begin{array}{l}\text { Fruit, oil, } \\
\text { fiber (coir) }\end{array}$ & Southeast Asia & $\begin{array}{l}\text { Philippines, } \\
\text { Indonesia, India, } \\
\text { Sri Lanka }\end{array}$ & $\begin{array}{l}55,234,124 \\
\text { (fruit), } \\
954,290 \text { (coir) }\end{array}$ \\
\hline & & & $\begin{array}{l}\text { Oil palm, } \\
\text { Elaeis guineensis }\end{array}$ & Oil & West Africa & Indonesia, Malaysia & $\begin{array}{l}173,391,199 \\
\text { (fruit) }\end{array}$ \\
\hline & & & $\begin{array}{l}\text { Date, } \\
\text { Phoenix dactylifera }\end{array}$ & Fruit & $\begin{array}{l}\text { N. Africa, } \\
\text { Middle East }\end{array}$ & Iraq, Iran, Egypt & $6,921,950$ \\
\hline & \multirow[t]{7}{*}{ Poales } & Bromilaceae & $\begin{array}{l}\text { Pineapple, } \\
\text { Ananas comosus }\end{array}$ & Fruit & South America & $\begin{array}{l}\text { Thailand, } \\
\text { Philippines, Brazil }\end{array}$ & $16,769,660$ \\
\hline & & $\begin{array}{l}\text { Poaceae } \\
\text { (Bambusoideae) }\end{array}$ & $\begin{array}{l}\text { Bamboos, many } \\
\text { genera }\end{array}$ & $\begin{array}{l}\text { Timber, } \\
\text { fiber }\end{array}$ & Mostly tropical & Mostly tropical & N.A. \\
\hline & & $\begin{array}{l}\text { Poaceae } \\
\text { (Ehrhartoideae) }\end{array}$ & Rice, Oryza sativa & Grain & IndoChina & Global & $618,440,644$ \\
\hline & & $\begin{array}{l}\text { Poaceae } \\
\text { (Pooideae) }\end{array}$ & Oats, Avena spp. & Grain & Europe & Temperate world & $23,953,749$ \\
\hline & & & $\begin{array}{l}\text { Barley, } \\
\text { Hordeum vulgare }\end{array}$ & Grain & $\begin{array}{l}\text { Southwest } \\
\text { Asia }\end{array}$ & $\begin{array}{l}\text { Europe, N. Africa, } \\
\text { Near East, Russia, } \\
\text { China, India, } \\
\text { Canada, USA }\end{array}$ & $139,043,947$ \\
\hline & & & Rye, Secale cereale & Grain & $\begin{array}{l}\text { Southwestern } \\
\text { Asia }\end{array}$ & Europe, Russia & $15,515,206$ \\
\hline & & & $\begin{array}{l}\text { Wheats, mainly } \\
\text { Triticum aestivum }\end{array}$ & Grain & Fertile Crescent & (continue & $\begin{array}{l}629,566,0417 \\
\text { d on next page) }\end{array}$ \\
\hline
\end{tabular}


Table 2. (Continued from previous page)

\begin{tabular}{|c|c|c|c|c|c|c|c|}
\hline & Order & $\begin{array}{l}\text { Family } \\
\text { (subfamily) }\end{array}$ & Crop(s), taxa & $\begin{array}{l}\text { Category/ } \\
\text { usage }\end{array}$ & $\begin{array}{l}\text { Center } \\
\text { of originv }\end{array}$ & $\begin{array}{l}\text { Major production } \\
\text { areas }\end{array}$ & $\begin{array}{l}\text { Production, } \\
2005(t)\end{array}$ \\
\hline & & $\begin{array}{l}\text { Poaceae } \\
\text { (Panicoideae) }\end{array}$ & $\begin{array}{l}\text { Sugarcane, } \\
\text { Saccharum spp. }\end{array}$ & Sugar & New Guinea & India, Cuba, Brazil & $1,291,685,924$ \\
\hline & & & $\begin{array}{l}\text { Millets, Eleusine } \\
\text { coracana, Pennisetum } \\
\text { americanum }\end{array}$ & Grain & Africa & & $28,559,553$ \\
\hline & & & $\begin{array}{l}\text { Sorghum, } \\
\text { Sorghum bicolor }\end{array}$ & Grain & Africa & Global & $58,668,212$ \\
\hline & & & Maize, Zea mays & Grain & $\begin{array}{l}\text { Mexico, } \\
\text { C. America }\end{array}$ & Global & $\begin{array}{l}710,675,149 \\
(\text { dry + green })\end{array}$ \\
\hline & Zingiberales & Musaceae & Banana $^{\mathrm{y}}$, Musa spp. & Fruit & Southeast Asia & $\begin{array}{l}\text { Tropical America, } \\
\text { Africa }\end{array}$ & $105,815,354$ \\
\hline & & & $\begin{array}{l}\text { Abacá (Manila } \\
\text { hemp), Musa textilis }\end{array}$ & Fiber & Philippines & $\begin{array}{l}\text { Philippines, Central } \\
\text { America }\end{array}$ & 100,987 \\
\hline & & & $\begin{array}{l}\text { Ginger, Zingiber } \\
\text { officinale }\end{array}$ & Spice & Southeast Asia & India, Southeast Asia & $1,004,546$ \\
\hline \multirow{23}{*}{$\begin{array}{l}\text { Eudicots } \\
\text { (tricolpates) }\end{array}$} & & & $\begin{array}{l}\text { Quinoa, } \\
\text { Chenopodium } \\
\text { quinoa }\end{array}$ & Grain & Andes & Andes & 57,765 \\
\hline & & & $\begin{array}{l}\text { Sugar beet, } \\
\text { Chenopodium } \\
\text { vulgaris }\end{array}$ & Sugar & Europe & $\begin{array}{l}\text { Europe, Russia, } \\
\text { USA }\end{array}$ & $240,984,299$ \\
\hline & & & $\begin{array}{l}\text { Spinach, } \\
\text { Spinacia oleracea }\end{array}$ & Vegetable & SW Asia & Europe, Americas & $12,980,944$ \\
\hline & Polygonales & Polygonaceae & $\begin{array}{l}\text { Buckwheat, } \\
\text { Fagopyrum spp. }\end{array}$ & grain & $\begin{array}{l}\text { Temperate } \\
\text { E. Asia }\end{array}$ & $\begin{array}{r}\text { Russia, France, } \\
\text { USA, Canada }\end{array}$ & $2,649,524$ \\
\hline & Saxifragales & Grossulariaceae & $\begin{array}{l}\text { Gooseberry, } \\
\text { Ribes spp. }\end{array}$ & Fruit & $\begin{array}{l}\text { Europe, } \\
\text { N. America }\end{array}$ & & 134,452 \\
\hline & & & Currant, Ribes spp. & Fruit & Europe & & 862,232 \\
\hline & Vitales & Vitaceae & $\begin{array}{l}\text { Grapes, mainly Vitus } \\
\text { vinifera }\end{array}$ & Fruit & C. Asia & $\begin{array}{l}\text { Mediterranean } \\
\text { Europe, USA }\end{array}$ & $65,584,122$ \\
\hline & Malpighiales & Euphorbiaceae & Tung, Aleurites spp. & Oil & East Asia & $\begin{array}{l}\text { China, Argentina, } \\
\text { USA, Brazil }\end{array}$ & 517,480 \\
\hline & & & $\begin{array}{l}\text { Cassava, } \\
\text { Manihot esculenta }\end{array}$ & $\begin{array}{l}\text { Root and } \\
\text { tuber }\end{array}$ & South America & $\begin{array}{l}\text { South America, } \\
\text { Africa }\end{array}$ & $203,061,895$ \\
\hline & & & $\begin{array}{l}\text { Castor (bean), } \\
\text { Ricinus communis }\end{array}$ & Oil & Africa? & $\begin{array}{l}\text { Brazil, India, Russia, } \\
\text { China }\end{array}$ & $1,393,812$ \\
\hline & & Linaceae & $\begin{array}{l}\text { Flax, linseed, } \\
\text { Linum usitatissimum }\end{array}$ & Fiber, oil & Eurasia & Temperate world & $\begin{array}{l}887,227 \\
\text { (fiber), } \\
693,000 \text { (seed) }\end{array}$ \\
\hline & & Passifloraceae & $\begin{array}{l}\text { Passionfruit, } \\
\text { Passiflora spp. }\end{array}$ & Fruit & $\begin{array}{l}\text { Tropical } \\
\text { America }\end{array}$ & Tropical America & $1,000,000$ \\
\hline & & Salicaceae & $\begin{array}{l}\text { Aspens and poplars, } \\
\text { Populus spp., }\end{array}$ & Timber, pulp & $\begin{array}{l}\text { Temperate to } \\
\text { arctic north }\end{array}$ & $\begin{array}{l}\text { Temperate to arctic } \\
\text { north }\end{array}$ & N.A. \\
\hline & Fabales & $\begin{array}{l}\text { Fabaceae } \\
\text { (Papilionoideae) }\end{array}$ & $\begin{array}{c}\text { Peanut (groundnut), } \\
\text { Arachis hypogaea }\end{array}$ & Pulse, oil & $\begin{array}{l}\text { Argentina, } \\
\text { Bolivia }\end{array}$ & & $35,865,389$ \\
\hline & & & $\begin{array}{l}\text { Pigeon pea, } \\
\text { Cajanus cajan }\end{array}$ & Pulse & India & India & $3,476,995$ \\
\hline & & & $\begin{array}{l}\text { Chickpea, } \\
\text { Cicer arietinum }\end{array}$ & Pulse & Western Asia & India, Mediterranean & $8,694,192$ \\
\hline & & & Soybean, Glycine max & $\begin{array}{l}\text { Oil, pulse, } \\
\text { forage }\end{array}$ & Northeast Asia & USA, South America & $214,347,289$ \\
\hline & & & Lentil, Lens culinaris & Pulse & Near East & $\begin{array}{l}\text { India, Pakistan, } \\
\text { Ethiopia, Near East, } \\
\text { Mediterranean }\end{array}$ & $4,059,587$ \\
\hline & & & $\begin{array}{l}\text { Alfalfa (lucerne), } \\
\text { Medicago sativa }\end{array}$ & Forage & Iran & $\begin{array}{l}\text { N. America, Europe, } \\
\text { S. America }\end{array}$ & N.A. \\
\hline & & & $\begin{array}{l}\text { Lima bean, } \\
\text { Phaseolus lunatus }\end{array}$ & Pulse & $\begin{array}{c}\text { Middle, S. } \\
\text { America }\end{array}$ & Subtropics, tropics & N.A. \\
\hline & & & $\begin{array}{l}\text { Common bean, } \\
\text { Phaseolus vulgaris }\end{array}$ & Pulse & $\begin{array}{c}\text { Middle, S. } \\
\text { America }\end{array}$ & Global & $\begin{array}{l}25,160,509 \\
(\text { dry + green })\end{array}$ \\
\hline & & & Pea, Pisum sativum & Pulse & Near East? & $\begin{array}{l}\text { N. Europe, Russia, } \\
\text { China, NW USA }\end{array}$ & $\begin{array}{l}20,283,678 \\
(\text { dry }+ \text { green })\end{array}$ \\
\hline & & & $\begin{array}{l}\text { Clovers, } \\
\text { Trifolium spp. }\end{array}$ & Forage & $\begin{array}{l}\text { Eastern } \\
\text { Mediterranean }\end{array}$ & Temperate world & N.A. \\
\hline
\end{tabular}


Table 2. (Continued from previous page)

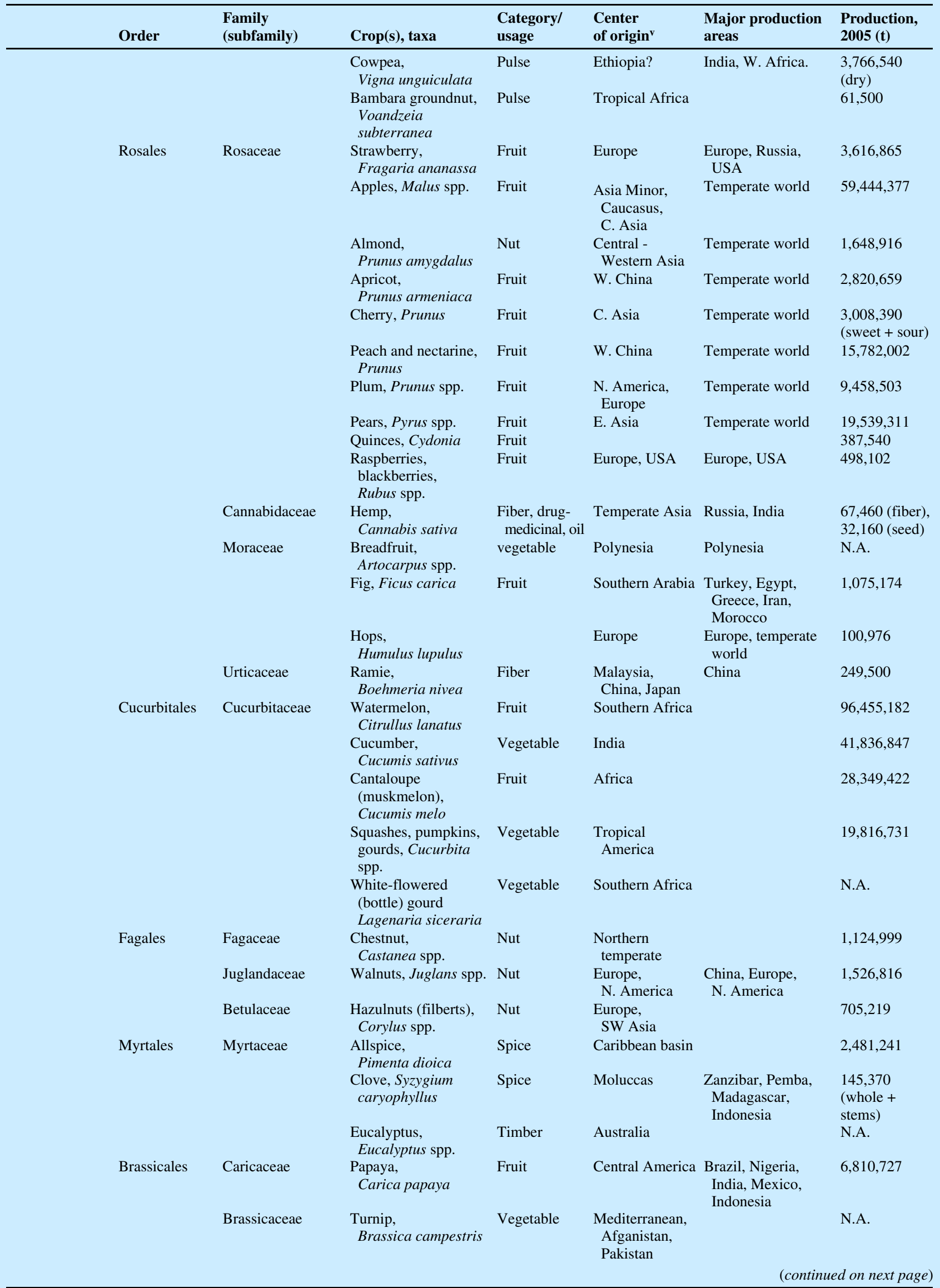


Table 2. (Continued from previous page)

\begin{tabular}{|c|c|c|c|c|c|c|}
\hline Order & $\begin{array}{l}\text { Family } \\
\text { (subfamily) }\end{array}$ & Crop(s), taxa & $\begin{array}{l}\text { Category/ } \\
\text { usage }\end{array}$ & $\begin{array}{l}\text { Center } \\
\text { of origin }^{v}\end{array}$ & $\begin{array}{l}\text { Major production } \\
\text { areas }\end{array}$ & $\begin{array}{l}\text { Production, } \\
2005(t)\end{array}$ \\
\hline & & $\begin{array}{l}\text { Cabbages, kales, } \\
\text { cauliflower, } \\
\text { broccoli, Brassica } \\
\text { oleracea }\end{array}$ & Vegetable & $\begin{array}{l}\text { Mediterranean, } \\
\text { Asia Minor }\end{array}$ & & $86,200,900$ \\
\hline & & $\begin{array}{l}\text { Swedes, rapes, } \\
\text { Brassica napus }\end{array}$ & Vegetable & $\begin{array}{l}\text { Europe- } \\
\text { Mediterranea }\end{array}$ & & N.A. \\
\hline & & $\begin{array}{l}\text { Mustards, Brassica } \\
\text { spp., Sinapis alba }\end{array}$ & Vegetable & & & 623,253 (seed) \\
\hline & & $\begin{array}{l}\text { Radish, } \\
\text { Raphanus sativus }\end{array}$ & Vegetable & $\begin{array}{l}\text { Mideast- } \\
\text { Mediterranean? }\end{array}$ & & N.A. \\
\hline \multirow[t]{7}{*}{ Malvales } & $\begin{array}{l}\text { Malvaceae } \\
\text { (Malvoideae) }\end{array}$ & $\begin{array}{l}\text { Okra, Abelmoschus } \\
\text { esculentus }\end{array}$ & Vegetable & $\begin{array}{l}\text { W. Africa } \\
\text { (Ethiopia?) }\end{array}$ & Subtropics, tropics & $5,041,694$ \\
\hline & & $\begin{array}{l}\text { Cottons, } \\
\text { Gossypium spp. }\end{array}$ & Fiber, oil & Mostly tropics & Global & $\begin{array}{l}18,586,467 \\
\text { (lint), } \\
33,442,393 \\
\text { (cottonseed) }\end{array}$ \\
\hline & $\begin{array}{l}\text { Malvaceae } \\
\text { (Bombacoideae) }\end{array}$ & $\begin{array}{l}\text { Kapok, } \\
\text { Ceiba pentandra }\end{array}$ & Fiber & $\begin{array}{l}\text { Tropical } \\
\text { America }^{z}\end{array}$ & Southeast Asia & $\begin{array}{l}122,000 \text { (fiber), } \\
392,967 \text { (fruit), } \\
331,296 \text { (seed } \\
\text { in shell) }\end{array}$ \\
\hline & $\begin{array}{l}\text { Malvaceae } \\
\text { (Sterculoidiae) }\end{array}$ & Kola(nut), Cola nitida & $\begin{array}{l}\text { Drug- } \\
\text { medicinal }\end{array}$ & W. Africa & W. Africa & 221,000 \\
\hline & $\begin{array}{l}\text { Malvaceae } \\
\text { (Tilioideae) }\end{array}$ & Jute, Corchorus spp. & Fiber & India & India & $3,250,322$ \\
\hline & $\begin{array}{l}\text { Malvaceae } \\
\text { (Byttnerioideae) }\end{array}$ & $\begin{array}{l}\text { Cacao, Theobroma } \\
\text { cacao }\end{array}$ & $\begin{array}{l}\text { Confectionary, } \\
\text { beverage }\end{array}$ & South America & West Africa & $\begin{array}{l}3,822,009 \\
\text { (beans) }\end{array}$ \\
\hline & Dipterocarpaceae & $\begin{array}{l}\text { Dipterocarps, Shorea } \\
\text { spp., Hopea spp., } \\
\text { Dipterocarpus spp., } \\
\text { Vatica spp. }\end{array}$ & Timber & Southeast Asia & Southeast Asia & N.A. \\
\hline \multirow[t]{5}{*}{ Sapindales } & Rutaceae & Citrus, Citrus spp. & Fruit & Southeast Asia & USA, Brazil & $105,440,168$ \\
\hline & Meliaceae & $\begin{array}{l}\text { Mahoganies, } \\
\text { Swietenia spp., } \\
\text { Khaya spp. }\end{array}$ & Timber & Tropics & Tropics & N.A. \\
\hline & Anacardiaceae & $\begin{array}{l}\text { Cashew, Anacardium } \\
\text { occidentale }\end{array}$ & Fruit, nut & $\begin{array}{l}\text { Tropical } \\
\text { America }\end{array}$ & Tropical America & $\begin{array}{l}1,718,010 \\
\text { (cashewapple) } \\
2,337,358 \\
\text { (cashew nut) }\end{array}$ \\
\hline & & $\begin{array}{l}\text { Mango, } \\
\text { Mangifera indica }\end{array}$ & Fruit & $\begin{array}{l}\text { India, Southeast } \\
\text { Asia }\end{array}$ & $\begin{array}{l}\text { India, China, } \\
\text { Mexico, Thailand, } \\
\text { Pakistan }\end{array}$ & $28,221,510$ \\
\hline & & $\begin{array}{l}\text { Pistachio, } \\
\text { Pistacia vera }\end{array}$ & Nut & C. Asia & Near East & 489,209 \\
\hline \multirow[t]{6}{*}{ Ericales } & Sapotaceae & $\begin{array}{l}\text { Karite (shea) nut, } \\
\text { Butyrospermum } \\
\text { paradoxum }\end{array}$ & Oil & W. Africa & W. Africa & 693,000 \\
\hline & Actinidiaceae & $\begin{array}{l}\text { Kiwifruit (Chinese } \\
\text { gooseberry), } \\
\text { Actinidia deliciosa }\end{array}$ & Fruit & S. China & New Zealand, Chile & $1,120,938$ \\
\hline & Ebenaceae & $\begin{array}{l}\text { Persimmon, } \\
\text { Diospyros kaki }\end{array}$ & Fruit & Asia & $\begin{array}{l}\text { Asia, N. America, } \\
\text { S. Europe }\end{array}$ & $2,561,732$ \\
\hline & Theaceae & $\begin{array}{l}\text { Tea, } \\
\text { Camellia sinensis }\end{array}$ & Beverage & China & China, India & $3,436,180$ \\
\hline & Lecythidaceae & $\begin{array}{l}\text { Brazilnut, } \\
\text { Bertholletia excelsa }\end{array}$ & Nut & $\begin{array}{l}\text { Northern } \\
\text { S. America }\end{array}$ & Bolivia, Brazil & 73,960 \\
\hline & Ericaceae & $\begin{array}{l}\text { Blueberry, cranberry, } \\
\text { Vaccinum spp. }\end{array}$ & Fruit & $\begin{array}{l}\text { N., S. America, } \\
\text { Europe }\end{array}$ & & $\begin{array}{l}242,610 \\
386,160\end{array}$ \\
\hline \multirow[t]{6}{*}{ Solanales } & Convolvulaceae & $\begin{array}{l}\text { Sweet potato, } \\
\text { Ipomea batatas }\end{array}$ & $\begin{array}{l}\text { Root and } \\
\text { tuber }\end{array}$ & $\begin{array}{l}\text { Tropical } \\
\text { America }\end{array}$ & Subtropics, tropics & $129,392,309$ \\
\hline & Solanaceae & $\begin{array}{l}\text { Pepper, chile, } \\
\text { Capsicum spp. }\end{array}$ & $\begin{array}{l}\text { Vegetable, } \\
\text { spice }\end{array}$ & $\begin{array}{l}\text { Tropical } \\
\text { America }\end{array}$ & $\begin{array}{l}\text { Temperate, tropical } \\
\text { world }\end{array}$ & $24,941,587$ \\
\hline & & $\begin{array}{l}\text { Tomato, } \\
\text { Lycospersicon } \\
\text { esculentum }\end{array}$ & Vegetable & $\begin{array}{l}\text { Tropical } \\
\text { America }\end{array}$ & Global & $122,659,873$ \\
\hline & & $\begin{array}{l}\text { Tobacco, } \\
\text { Nicotiana tabacum }\end{array}$ & $\begin{array}{l}\text { Drug- } \\
\text { medicial }\end{array}$ & $\begin{array}{l}\text { Tropical } \\
\text { America }\end{array}$ & Global & $6,564,017$ \\
\hline & & $\begin{array}{l}\text { Eggplant (aubergine), } \\
\text { Solanum melongena }\end{array}$ & Vegetable & India? & Subtropics, tropics & $30,477,775$ \\
\hline & & $\begin{array}{l}\text { Potato, } \\
\text { Solanum tuberosum }\end{array}$ & $\begin{array}{l}\text { Root and } \\
\text { tuber }\end{array}$ & $\begin{array}{l}\text { Tropical } \\
\text { America }\end{array}$ & Global & $323,102,918$ \\
\hline
\end{tabular}


Table 2. (Continued from previous page)

\begin{tabular}{|c|c|c|c|c|c|c|}
\hline Order & $\begin{array}{l}\text { Family } \\
\text { (subfamily) }\end{array}$ & $\operatorname{Crop}(s)$, taxa & $\begin{array}{l}\text { Category/ } \\
\text { usage }\end{array}$ & $\begin{array}{l}\text { Center } \\
\text { of origin }\end{array}$ & $\begin{array}{l}\text { Major production } \\
\text { areas }\end{array}$ & $\begin{array}{l}\text { Production, } \\
2005(t)\end{array}$ \\
\hline \multirow[t]{2}{*}{ Gentianales } & \multirow[t]{2}{*}{ Rubiaceae } & $\begin{array}{l}\text { Cinchona (quinine), } \\
\text { Cinchona spp. }\end{array}$ & $\begin{array}{l}\text { Drug- } \\
\text { medicinal }\end{array}$ & Andes & Indonesia & N.A. \\
\hline & & $\begin{array}{l}\text { Coffees, } \\
\text { Coffea arabica, } \\
\text { C. canephora }\end{array}$ & Beverage & $\begin{array}{l}\text { Ethiopia, } \\
\text { W. Africa }\end{array}$ & Tropical America & $\begin{array}{l}7,779,495 \\
\text { (green beans) }\end{array}$ \\
\hline \multirow[t]{3}{*}{ Lamiales } & Oleaceae & Olive, Olea europaea & Oil & \multirow[t]{2}{*}{ Mediterranean } & \multirow[t]{2}{*}{ Spain, Italy, Greece } & $14,442,435$ \\
\hline & Lamiaceae & $\begin{array}{l}\text { Teak, } \\
\text { Tectona grandis }\end{array}$ & Timber & & & N.A. \\
\hline & Pedaliaceae & $\begin{array}{l}\text { Sesame, } \\
\text { Sesamum indicum }\end{array}$ & Oil & Africa? & $\begin{array}{l}\text { India, China, Sudan, } \\
\text { Mexico, Venezuela, } \\
\text { Burma }\end{array}$ & $3,325,679$ \\
\hline Apiales & Apiaceae & Carrot, Daucus carota & Vegetable & Afganistan & \multirow{3}{*}{$\begin{array}{l}\text { Temperate world } \\
\text { India, USA, Mexico }\end{array}$} & $24,481,021$ \\
\hline \multirow[t]{5}{*}{ Asterales } & \multirow[t]{5}{*}{ Asteraceae } & $\begin{array}{l}\text { Safflower, Carthamus } \\
\text { tinctorius }\end{array}$ & Oil & Near East & & 805,667 \\
\hline & & $\begin{array}{l}\text { Pyrethrum, } \\
\text { Chrysanthemum spp. }\end{array}$ & Insecticidal & $\begin{array}{l}\text { Caucasus, NW } \\
\text { Persia }\end{array}$ & & $\begin{array}{l}13,405 \\
\text { (dry flowers) }\end{array}$ \\
\hline & & $\begin{array}{l}\text { Sunflower, } \\
\text { Helianthus annuus }\end{array}$ & Oil & $\begin{array}{l}\text { Midwestern } \\
\text { USA }\end{array}$ & $\begin{array}{l}\text { Russia, Argentina, } \\
\text { Balkans }\end{array}$ & $30,944,162$ \\
\hline & & $\begin{array}{l}\text { (Globe) artichoke, } \\
\text { Cynara cardunculus }\end{array}$ & Vegetable & $\begin{array}{l}\text { Mediterranean, } \\
\text { Canary Islands }\end{array}$ & Europe, USA & $1,203,775$ \\
\hline & & Lettuce, Lactuca spp. & Vegetable & $\begin{array}{l}\text { Eastern } \\
\text { Mediterranean }\end{array}$ & $\begin{array}{l}\text { N. America, } \\
\text { Australia, Europe, } \\
\text { S. America }\end{array}$ & $22,204,280$ \\
\hline
\end{tabular}

and bacteria, whereas water deficits can predispose crops to other diseases $(39,101,107)$. Insect damage and other diseases are among the biotic factors that affect host susceptibility $(101,131,147)$. For example, canker and Phytophthora root rot, caused by Phytophthora palmivora, are diseases of citrus whose severities are increased by, respectively, the citrus leaf miner, Phyllocnistis citrella, and the Diaprepes root weevil, Diaprepes $a b$ breviatus (150), whereas the development of anthracnose of avocado, caused by $\mathrm{Col}$ letotrichum gloeosporioides, is increased by scab damage, caused by Sphaceloma perseae (95).

In perennial systems, there are increased opportunities for pathogen movement within and among plantations. This occurs with all contagious diseases, but can be especially important with slow-moving diseases that might retain a restricted distribution in a short-season crop $(107,140,166)$. Given sufficient time, even sedentary soilborne problems can spread significantly.

When explosive aboveground diseases are involved, new strains (47) or taxa (151) that are more fit or virulent than pre-existing populations can rapidly increase to dominate a field or region. This process is most rapid when there is no seasonal opportunity to change to resistant genotypes and hosts are grown in monocultures. Diseases are usually far less damaging in intercropped production (147) and in natural ecosystems $(15,17)$ than they are in uniform plantings. Yellow rust of coffee, Coffea arabica, caused by Hemileia vastatrix, and South American leaf blight of Para rubber, Hevea brasiliensis, caused by Microcyclis ulei, are two examples of dis- eases that are innocuous in mixed or natural systems but become enormous problems in monocultures $(40,92)$.

Multilines and cultivar mixtures have been used to discourage epidemic disease development in annual crops, and rusts and powdery mildews of cereals are common targets $(49,98)$. This approach is relatively uncommon with perennials, especially when cultivar identity is required in the marketplace. There is also evidence to suggest that when hosts are large, autoinfection may negate the beneficial impact of heterogeneous host mixes $(17,49,116)$. In a recent review, Mundt (98) mentioned only one perennial crop in the tropics, coffee, in which mixes of resistant cultivars were used to combat rust.

Replacing susceptible perennial hosts is costly, and it often takes several years before widespread changes can be made. Schieber (130) indicated that it took about 10 years for rust-susceptible coffee cultivars to be replaced; and the transition to Cavendish cultivars that resisted Panama disease, caused by Fusarium oxysporum f. sp. cubense, in the American banana trades took a decade or longer (140).

Finally, perennial crops are more apt to be affected by variable production or economic factors than annual crops. The impact of coffee rust provides examples. Avelino et al. (7) demonstrated that seasonal and site-specific variation affected the development of coffee rust and resultant yield; fungicidal management of this disease was justified only in some years and some locations. In marginal production areas where low yield potentials resulted in narrow profit margins, the use of fungicides was never justified (130). In these areas, rust-resistant cultivars were most important $(118,133)$. Given the dramatic fluctuations that occur in global coffee prices (1), it is reasonable to assume that fungicide applications for rust control would be reduced if market returns were low.

\section{Diseases \\ of Tropical Perennial Crops}

The disease challenges that face producers of tropical perennial crops are outlined in the following sections. As discussed above, the overall picture is one of diverse pathogens and host plants in what are often disease-conducive environments $(148,161)$. These are difficult problems. Due to their polycyclic nature, measures that are useful on annual or short-term crops may be ineffective. In general, more effective and durable management options are needed in perennial situations, especially when there is no winter or off-season during which inoculum and disease pressure would be reduced (see Buddenhagen [14] for a contrasting view). It is not surprising that diseases can be serious constraints in the production of tropical perennials, and that special strategies may be needed to effect their management.

Below, some basic concepts are presented on the occurrence and development of these pathosystems. Peculiar aspects of these diseases and scenarios that influence the types and the extent to which they develop are summarized. They are scientifically interesting problems. New vectors (mango malformation) or pathogens (bunchy top of papaya) are associated with some of these diseases, and several are caused by two or more taxa, for example, bud rot of betel nut and coconut, citrus greening, mango malformation, Panama disease, phytoplasma diseases of coconut, 
and tracheomycosis of coffee $(29,58,89$, 107, 109,117,123,150; C. S. Lima, L. H. Pfenning, S. S. Costa, M. A. Campos, and J. F. Leslie, unpublished). Some of the most important diseases are host-specific or have restricted host ranges; they are caused by either coevolved or newencounter pathogens. Resistance, the most effective tool with which many of these diseases are managed, is usually available in coevolved pathosystems but is uncommon in some new-encounter situations. Inadequate host resistance represents a significant barrier to managing many new-encounter diseases.

This review concludes with general tactics that are useful against diseases of tropical perennials. The successful management of plant disease utilizes several principles and practices, regardless of the host and the environment in which it is grown $(101,143,154,165)$. These include the avoidance, exclusion, and eradication of the causal agents. Host protection is of great importance, as is the identification and incorporation of resistance in the host plant. All of these approaches are discussed with tropical perennial examples.

Coevolved pathosystems. Although the term "coevolution" was first coined in 1964 to describe butterfly:plant interactions (38), the idea that tandem evolution occurs between species was discussed by Darwin (26) and described in the 1950s in a plant-pathological context (20). In describing results from his classic research on flax rust, Flor (46) suggested that "...obligate parasites, such as the rust fungi, must have evolved in association with their hosts" and that "...during their parallel evolution, host and parasite developed complementary genic systems." Gene-for-gene systems have now been identified in many other pathosystems, and the specific adaptation of pathogens to host taxa, such as those described as formae speciales, is generally accepted as "the outcome of coevolution" (25).

These relationships can be conceived of as arms races in which increased disease resistance develops in a host in response to increased virulence in a pathogen $(10,74)$. The flux of resistant, rare host genotypes and susceptible, common genotypes has been studied most closely for obligate pathogens that have specific host ranges and possess the complementary gene-forgene relationships described first by Flor (46), but it also occurs in nonobligate situations (25).

Coevolutionary interactions are spatially and temporally complex and thus can be difficult to study and document $(10,16$, 146). And there are reasons why coevolution might not develop between cooccurring hosts and pathogens, even when these are obligate relationships (122). For example, insufficient genetic variation may exist in the host or pathogen for coevolution to occur, or the pathogen may not speciate at the same time as the host (122). Nonetheless, coevolution appears to be an important factor in the development of many pathosystems (17). Several criteria can be used to identify possible coevolved pathosystems $(10,16,19,25,46$, $53,57,62,129,136,146)$. These include:

- a limited, often specific host range for the pathogen;

- an original geographic distribution of the pathogen that overlaps with that of the host;

- the occurrence of significant disease resistance in the host's primary center of origin;

- regional overlap of resistance and pathogenicity factors and phenotypes in the respective host and pathogen populations (i.e., geographic evidence for reciprocal selection);

- gene-for-gene relationships; and

- $\quad$ tandem speciation (aka parallel cladogenesis).

Most examples of supposed coevolved pathosystems possess some, but not all, of these attributes $(25,40,92,112)$, and there are relatively few examples of unequivocal host-pathogen coevolution where unambiguous molecular data underpin the relationship $(62,129)$. However, the numbers of unequivocal coevolved pathosystems will surely increase as greater sophistication is used in the identification of these relationships and the coevolution process is better understood. In the meantime, coevolution will remain a useful concept for the study of host-pathogen interactions.

Centers of origin, the enemy release hypothesis, and new-encounter diseases. The great plant explorer Vavilov (155) recognized different geographic regions in which important sets of crops plants were domesticated and utilized by primitive societies, and where, subsequently, ancient civilizations began. The concept of agricultural centers of origin has been criticized, refined, and more fully developed in recent years $(33,56)$.

Although some of the centers that Vavilov (155) recognized might be questionable, centers of origin for domesticated crops are usually clear $(76,128,135)$. Genetic diversity is often greatest in the primary centers (where the crop first evolved), but can also be considerable in secondary centers. In extreme cases, distinct types of host plants may be found in secondary centers: for example, the East African Highland cooking bananas, highly diversified in upland East Africa but not found or unrecognized in the primary Southeast Asian home of banana $(71,134)$.

Given the heterogeneous nature of tropical environments, one might assume that tropical crops perform best where they evolved, i.e., under conditions to which they had adapted over time. In fact, significant production for many tropical crops occurs outside the native ranges (Table 3 ). Why is this so? Although several factors have been proposed, the absence of coevolved plant pathogens often plays a significant role. When species display enhanced fitness in new habitats, they have often been "released" from important coevolved enemies $(54,96)$.

The so-called "Enemy Release Hypothesis" has been used by ecologists to explain the development of weed species in new habitats. In an investigation of the hypothesis, Mitchell and Power (97) found $24 \%$ fewer viruses and $84 \%$ fewer rust, smut, and powdery mildew fungi on 473 nonendemic plant species in the United States than in their native habitats in Europe. Invasive weed species (those that were most fit) were more completely released from the pathogens (had fewer) than their nonweedy counterparts.

There are many examples of tropical crops that are most productive in nonnative habitats $(114,135)$. For some of these crops, the absence of a single or a few key pathogens is a pivotal reason for this productivity. The continued production of such crops in the new areas depends upon the continued exclusion of the pivotal (most dangerous) pathogens, and failure to do so can be costly. For example, the coevolved Sigatoka leafspot pathogens, $M y$ cosphaerella musicola and M. fijiensis, dramatically affected banana (Musa spp.) production whenever they were reunited with their host in new production areas.

Other tropical perennial crops that have been released from destructive, coevolved pathogens in new production areas include:

- banana, major production of which occurs outside Southeast Asia where tropical race 4 of $F$. oxysporum $\mathrm{f}$. sp. cubense does not occur (109);

- Para rubber, production of which predominates in Southeast Asia in the absence of South American leaf blight (40);

- $\quad$ pineapple, Ananas comosus, major production of which occurs where the coevolved fusariosis pathotype of Fusarium guttiforme is not found (117);

- $\quad$ coffee, Coffea arabica and C. robusta, most of which is produced outside Africa where coffee wilt disease (aka tracheomycosis), caused by Gibberella xylarioides (anamorph: Fusarium xylarioides) is found (123) (dissemination of another coevolved disease, yellow rust, has had a major impact on $C$. arabica production worldwide) (92) (Fig. 1);

- cacao, Theobroma cacao, $85 \%$ of which is produced where the coevolved witches'-broom pathogen, Moniliophthora (syn. Crinipellis) perniciosa, does not occur (110) (Fig. 2); and

- $\quad$ oil palm, Elaeis guineensis, more than $90 \%$ of which is produced outside West Africa (42). Until recently, Fusarium wilt, caused by $F$. oxysporum $\mathrm{f}$. 
sp. elaeidis, was found only in West Africa, where it coevolved with its host (45). Fusarium wilt has a major influence on oil palm production in Africa, and would undoubtedly impact the primary Southeast Asian production centers if it was moved there.

As mentioned above, resistant parents for coevolved hosts are often found in the respective centers of origin $(81,136)$. Prospecting in these areas for resistant parents is a common strategy used by breeding programs. Unfortunately, habitat destruction, deforestation, and mismanagement cause losses of these genetic resources $(21,30,40)$. The extinction of these valuable sources of disease and pest resistance, productivity, and environmental adaptibility is a serious problem.

Although resistant parents are usually available for the coevolved diseases, they may not be available for new-encounter diseases. Thus, new-encounter diseases can be just as devastating as coevolved diseases, but may be more difficult to control. Serious new-encounter examples for which little conventional resistance is known include Phytophthora root rot of avocado, caused by P. cinnamomi (166), and citrus greening, caused by three different 'Candidatus Liberobacter' spp. (S. Halbert, personal communication).

New-encounter diseases develop when a plant is confronted with a pathogen with which it has not had an evolutionary

Table 3. Selected coevolved and new encounter pathogens of tropical perennial crops

\begin{tabular}{|c|c|c|c|c|}
\hline \multirow[b]{2}{*}{ Crop } & \multirow{2}{*}{$\begin{array}{l}\text { Relative } \\
\text { production }^{\mathrm{x}}\end{array}$} & \multicolumn{2}{|c|}{ Pathogen (disease) ${ }^{\mathrm{w}}$} & \multirow[b]{2}{*}{ References } \\
\hline & & Coevolved & New encounter & \\
\hline Avocado & Moderate & $\begin{array}{l}\text { * Sphaceloma perseae (scab), } \\
\text { Mycosphaerella perseae (silver spot) }\end{array}$ & $\begin{array}{l}\text { *Phytophthora cinnamomi (Phytophthora } \\
\text { root rot) }\end{array}$ & $39,95,166$ \\
\hline Banana & Major & $\begin{array}{l}\text { * Fusarium oxysporum f. sp. cubense } \\
\text { (Panama disease), *Mycosphaerella } \\
\text { fijiensis and M. musicola (Sigatoka } \\
\text { leafspots), Uredo musae (rust) }\end{array}$ & $\begin{array}{l}\text { *Ralstonia solanacearum phylotype II } \\
\text { (Moko disease), *Xanthomonas } \\
\text { campestris pv. musaearum (xanthomonas } \\
\text { bacterial wilt) }\end{array}$ & $\begin{array}{l}13,43,112,140,141 \\
145,149,151,164^{y}\end{array}$ \\
\hline Cacao & Major & $\begin{array}{l}\text { *Moniliophthora perniciosa (witches'- } \\
\text { broom) }\end{array}$ & $\begin{array}{l}\text { *Moniliophthora rorei (frosty pod), } \\
\text { *Cacao swollen shoot virus (swollen } \\
\text { shoot), *Oncobasidium theobromae } \\
\text { (vascular streak dieback), *Phytophthora } \\
\text { megakarya (black pod), *Ceratocystis } \\
\text { cacaofunesta (vascular wilt) }\end{array}$ & $8,19,37,40,41,52$ \\
\hline Cinchona & Major & Phytophthora quininea & $\begin{array}{l}\text { Phytophthora cinnamomi, Phytophthora } \\
\text { nicotianae }\end{array}$ & 39,161 \\
\hline Citrus & Major & & $\begin{array}{l}\text { *'Candidatus Liberibacter africanus', } \\
\text { 'Candidatus Liberibacter asiaticus' and } \\
\text { 'Candidatus Liberibacter americanus' } \\
\text { (huanglongbing [greening]) } \mathrm{z} \text {, Xylella } \\
\text { fastidiosa (variegated chlorosis), } \\
\text { phytoplasma (witches'-broom of lime) }\end{array}$ & 115,150 \\
\hline Coconut & Moderate & & $\begin{array}{l}\text { *Phytoplasmas (lethal yellowing, Awka } \\
\text { wilt, coconut lethal disease, etc.), } \\
\text { Bursaphelenchus cocophilus (red ring), } \\
\text { Phytophthora katsurae (bud rot), } \\
\text { Phytomonas (hart rot) }\end{array}$ & 58 \\
\hline $\begin{array}{l}\text { Coffee, Coffea } \\
\text { arabica }\end{array}$ & Major & $\begin{array}{l}\text { *Gibberella (Fusarium) xylarioides } \\
\text { (tracheomycosis), Hemileia coffeicola } \\
\text { (grey rust), }{ }^{*} \text { Hemileia vastatrix (yellow } \\
\text { leaf rust) }\end{array}$ & $\begin{array}{l}\text { * Mycena citricolor (ojo de gallo), Xylella } \\
\text { fastidiosa (variegated chlorosis) }\end{array}$ & $\begin{array}{l}92,115,118,123,133, \\
152\end{array}$ \\
\hline Eucalyptus & Major & & Puccinia psidii (rust) & 24 \\
\hline $\begin{array}{l}\text { Guava, Psidium } \\
\text { guajava }\end{array}$ & Moderate & Puccinia psidii (rust) & Penicillium vermoesini ? (guava wilt) & 24,83 \\
\hline Mango & Moderate & *Fusarium mangiferae (malformation) & $\begin{array}{l}\text { *Fusarium sterilihyphosum and } \\
\text { *Fusarium } \mathrm{sp} \text {. (malformation); } \\
\text { *Ceratocystis fimbriata (seca, sudden } \\
\text { wilt) }\end{array}$ & $\begin{array}{l}3,89,106 \text {, and } \\
\text { footnote } y\end{array}$ \\
\hline Oil palm & Major & $\begin{array}{l}\text { *Fusarium oxysporum f. sp. elaeidis } \\
\text { (Fusarium wilt) }\end{array}$ & $\begin{array}{l}\text { *Thielaviopsis paradoxa? (pudricion } \\
\text { cogilla [bud rot]), Phytomonas } \\
\text { (marchitez sopresiva), *Ganoderma } \\
\text { boninense (ganoderma butt rot), } \\
\text { *Phytoplasma? (marchitez letal [lethal } \\
\text { wilt]) }\end{array}$ & $12,31,36,45,104$ \\
\hline Papaya & Major & & $\begin{array}{l}\text { *Papaya ringspot virus (papaya ringspot), } \\
\text { *Phytophthora palmivora (fruit, root, and } \\
\text { stem rot), *'Candidatus Phytoplasma } \\
\text { australasia' (papaya dieback, yellow } \\
\text { crinkle and mosaic) }\end{array}$ & 9,103 \\
\hline Pineapple & Major & *Fusarium guttiforme (fusariosis) & & 117 \\
\hline Rubber & Major & $\begin{array}{l}\text { *Microcylis ulei (South American leaf } \\
\text { blight) }\end{array}$ & & 40 \\
\hline
\end{tabular}


history (102). Two types of new encounters have been described (17).

The first, apparently uncommon (or at least not commonly documented), results from an evolutionary host jump. Genetic changes in the pathogen (somatic hybridization, chromosome loss, and recombination are among the mechanisms) result in its adaptation to a co-occurring, previously nonsusceptible host $(9,122,138)$.

The second kind of host jump results from dissemination of either the host or pathogen to effect a new interaction $(14,57)$. Often, the original host of the new-encounter pathogen is not known; examples include:

- Ceratocystis wilt of cacao, caused by Ceratocystis cacaofunesta in tropical America (8,37);

- seca or sudden decline of mango caused in Brazil and Oman by Ceratocystis fimbriata $(3,106)$ (Fig. $3)$;

- wilt of guava, Psidium guajava, caused in Malaysia, South Africa, and Taiwan by a fungus with unclear taxonomic affiliations (83);

- witches'-broom of lime, Citrus aurantifolia, caused in the Middle East by a phytoplasma (150) (Fig. 4);

- mango malformation, caused in Brazil (and possibly elsewhere in the Americas) by Fusarium sterilihyphosum, an unnamed mating population of the Gibberella fujikuroi species complex, and possibly other taxa (119; C. S. Lima, L. H. Pfenning, S. S. Costa, M. A. Campos, and J. F. Leslie, unpublished) (Fig. 5);

- vascular streak dieback of cacao, caused in Asia by Oncobasidium theobromae (52); and

- $\quad$ xanthomonas wilt of banana, caused in Africa by Xanthomonas campestris pv. musaearum (it was reported initially on a banana relative, Ensete ventricossum, but it is not clear whether this first host was coevolved or new encounter $[149,151,164]$ ) (Fig. $6)$.

When the original hosts of newencounter diseases are known, they are usually closely related to the newly encountered host. For example:

- Colletotrichum kahawae, cause of coffee berry disease, originated on Coffea eugenioides, a close relative (precursor?) of C. arabica (152) (Fig. 7);

- $\quad$ Moniliophthora rorei, cause of frosty pod of cacao, probably originated on Theobroma gileri (40) (Fig. 8);

- Ralstonia solanacearum phylotype II, cause of Moko disease of banana, evolved on banana relatives in the Americas, Heliconia spp. $(13,43)$ (Fig. 6);

- $\quad$ Ganoderma boninense, the basal stem rot pathogen of African oil palm, originated on coconut palm, Cocos nucifera, in Asia $(36,104)$; and

- Puccinia psidii, cause of rust of eucalyptus, Eucalyptus spp., originated on other genera and species in the Myrtaceae in the Americas (24).
Although new encounters usually occur over great distances, this is not always the case, and there are instances when newencounter pathogens evolved in close proximity to the new-encounter host. For example, $M$. rorei probably originated on

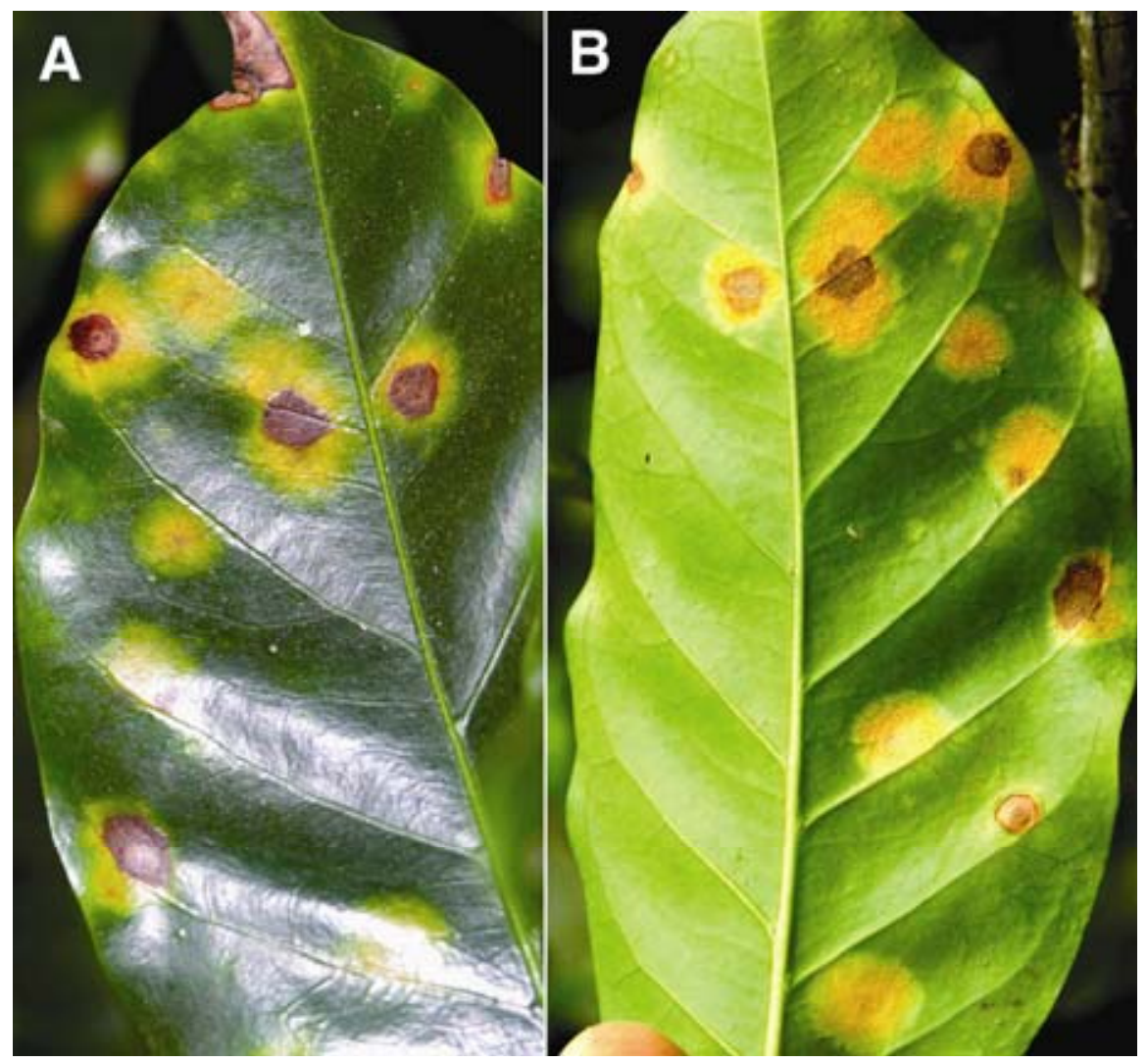

Fig. 1. A, Adaxial and B, abaxial surface of a leaf of coffee, Coffea arabica, affected by yellow rust, caused by Hemileia vastatrix. Rust caused little damage in natural, heterogeneous stands of coffee in Ethiopia, and in the arid Arabian Peninsula where the crop was first produced outside Africa. However, beginning in the late 1800s in humid Sri Lanka and India, the disease started to spread and cause serious damage in monoculture production.

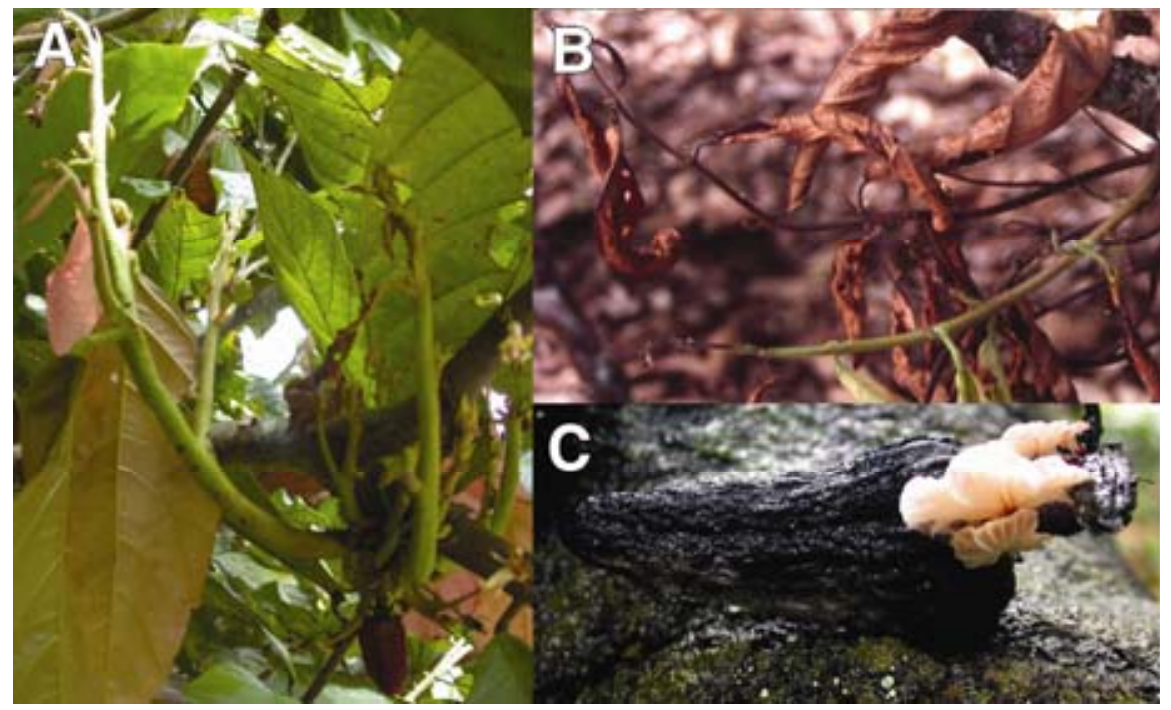

Fig. 2. Witches'-broom, caused by the hemibiotroph Moniliophthora perniciosa, is the most serious coevolved disease of cacao. A, Hypertrophied brooms are induced during the pathogen's biotrophic phase. B, Brooms die as the disease transitions from the biotrophic to the necrotic phase. C, Basidiomes of the pathogen form later on necrotic tissues, such as this pod. 


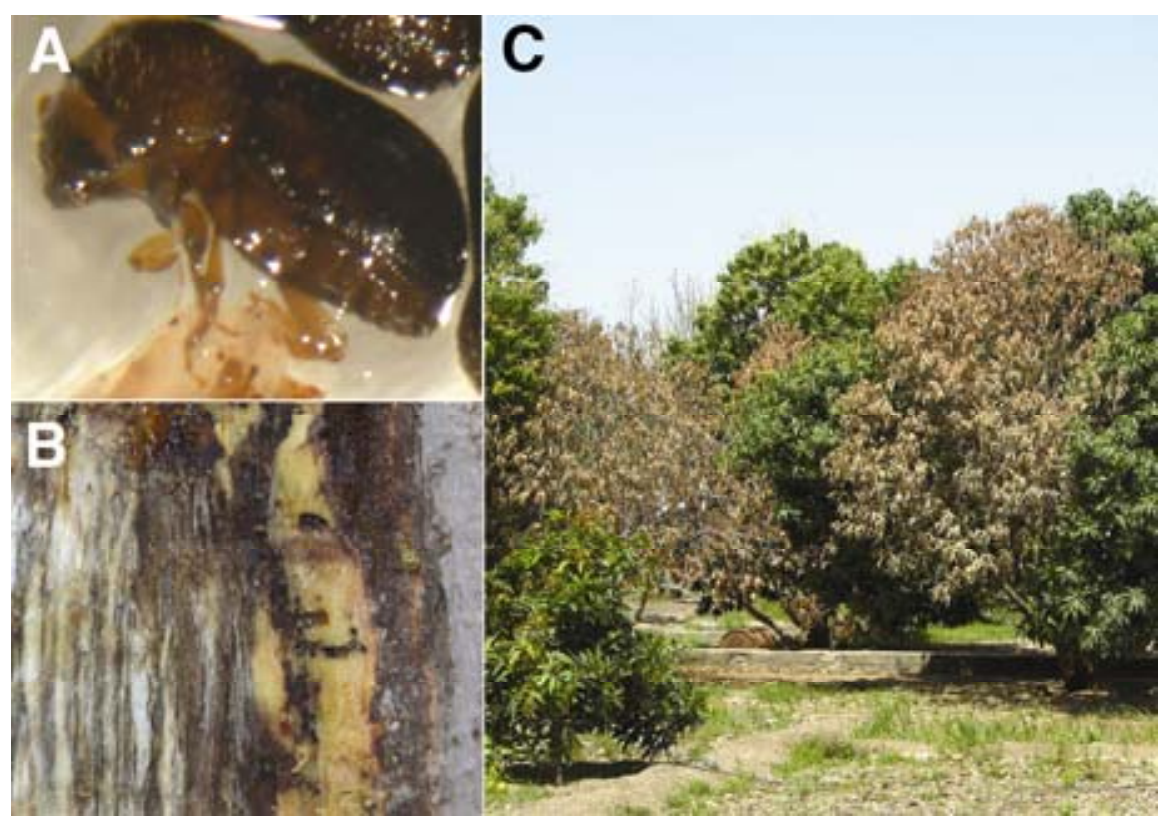

Fig. 3. The new-encounter disease known as seca and Recife sickness in Brazil and sudden wilt in Oman is caused by Ceratocystis fimbriata and vectored by $A$, the scolytid beetle, Hypocryphalus mangiferae. B, Internal symptoms caused by the disease and galleries of $\boldsymbol{H}$. mangiferae. C, Unilateral death of portions of affected trees in Oman; ultimately trees are killed. This disease is an example of failed quarantine measures, in that it was restricted to Brazil until it was recently introduced into Pakistan and Oman; it poses a grave threat to a primary center of mango germplasm in India.
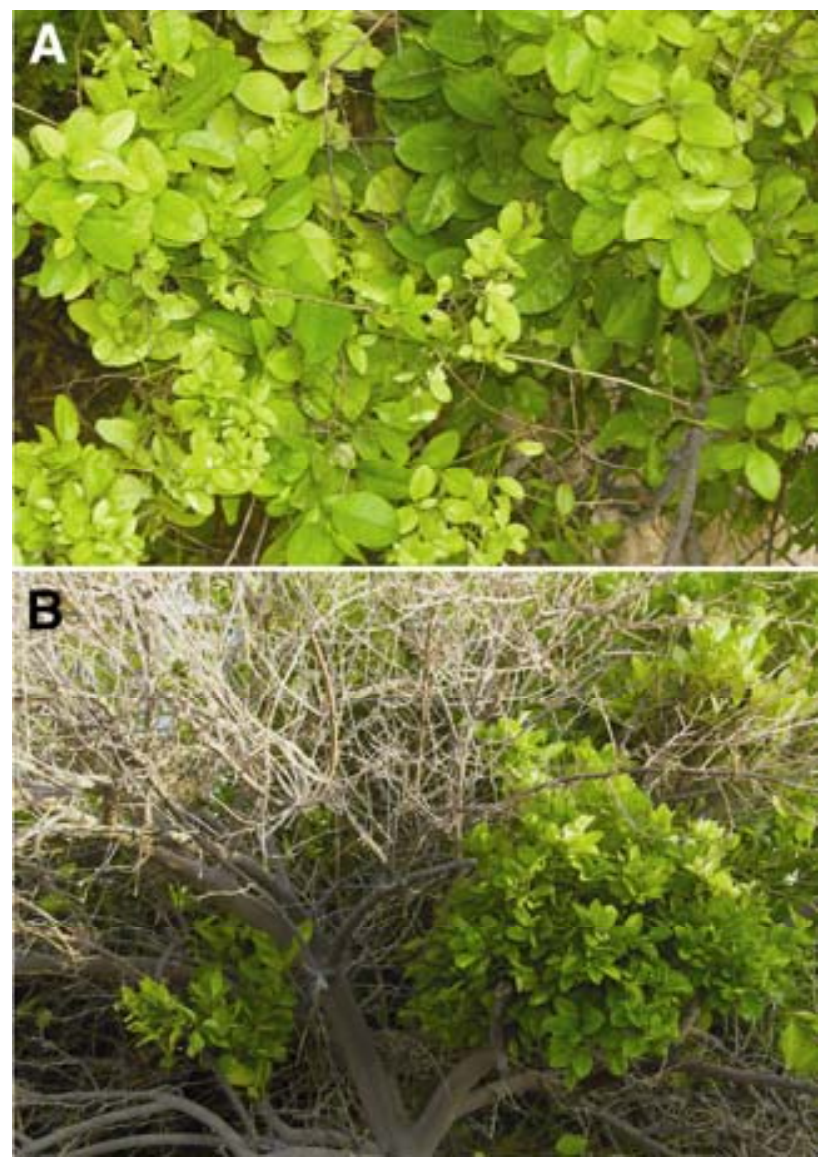

Fig. 4. Lime witches'-broom is one of several serious new-encounter diseases of citrus (here on Citrus aurantifolia). Found in the Middle East and caused by a phytoplasma, it initially, A, dwarfs and malforms terminal portions of the canopy and, B, later kills large portions of the tree. the western flank of the Andes, a short distance from the cacao center on the range's eastern flank (40).

\section{Disease Management in Tropical Perennial Crops}

To devise effective management strategies, it is usually necessary to understand the disease's etiology and epidemiology. When causal agents are not known, or when they cannot be cultured and used to artificially induce disease, it is usually not possible to test treatment efficacy in a controlled manner. Two debilitating citrus diseases provide examples: blight, which has an unknown etiology, and greening, which has at least three unculturable, putative agents (150). And even when causal agents are known, unclear epidemiologies or an inability to reproduce symptoms artificially with a given agent are significant handicaps. Both of these factors contribute to management problems with basal stem rot of oil palm, a disease that kills as many as $70 \%$ of the palms in plantations in Indonesia and Malaysia $(36,104)$.

In general, effective disease management relies on a delay in the onset or reduction in the intial levels of disease $\left(x_{\mathrm{O}}\right)$, or a reduction in the rate at which disease develops over time $(r)(154,165)$. Below, I briefly relate these epidemiological principles to the following tactics: avoidance, exclusion, and eradication of causal agents; protection of, or development of resistance in, the host plant; and treatment of affected plants.

Avoidance. Planting site selection is an important first step in establishing a production area, and can be an important tactic for disease avoidance $(101,165)$. In general, the conditions under which disease development is favored or hosts are predisposed to disease development should be considered. For example, swamp spot of banana, caused by Deightoniella torulosa, is exacerbated in low-lying and poorly drained situations, as are numerous root rots that are caused by stramenopiles $(39,107,141,153)$ (Fig. 9). By avoiding chronically wet sites, it is possible to reduce $x_{\mathrm{O}}$ for these diseases, but especially $r$.

Likewise, production areas in which hosts might be predisposed to disease development should be avoided. Predisposing factors are usually physical, but indirect in their impact (131). Water and temperature extremes are most often indicated, although optimal temperatures for the host might still lead to enhanced disease if it also favors the pathogen (101). For example, Phytophthora root rot of avocado is most severe between 15 and $27^{\circ} \mathrm{C}$, temperatures that are also optimum for the host (166). Physical damage to the host might also predispose it to disease development, and this can be abiotic, as is the case with wind damage and the development of bacterial black spot of mango, caused by Xanthomonas sp. pv. mangifer- 
aeindicae, or biotic, as for the enhanced development of citrus canker in leaves damaged by the citrus leafminer $(48,150)$. Managing the predisposing factors is always helpful.

The importance of using disease-free planting materials cannot be overstated, and any measure or legislation that would produce disease/pathogen free materials and disseminate them to growers would be useful (66). For example, clean nursery stock and budwood schemes are hallmarks of successful citrus programs (113).

Vegetative propagules can harbor bacteria, fungi, nematodes, viruses, and viroids, and it is with them that many economically important pathogens are moved and established (65). True seed are less apt to carry pathogens, but they can also pose significant risks. The key with both vegetative materials and true seed is to know what diseases can be moved in these ways on a given crop.

Tissue-culture plantlets should be used whenever possible, since they are free of fungal, bacterial, and nematode pathogens $\left(x_{\mathrm{O}}=0\right)$ (66). They are also free of virus and viroid pathogens when they are produced from indexed mother plants. Only in rare cases are tissue-culture plantlets not safe (the badnaviruses, such as Banana streak virus, cause exceptional problems; see ref. 84).

Many diseases of perennial crops originate in propagation nurseries, and soilborne diseases whose symptoms are not readily apparent can be most problematic. Phytophthora root rot of avocado is a good example. $P$. cinnamomi originated in New Guinea, but has been disseminated worldwide in contaminated planting stock (166). Its establishment in new avocado orchards usually results from planting trees that were infected in the nursery (95).

Exclusion. Diverse tactics exist for the exclusion of plant pathogens $(66,101)$. Although the idea that "there is no disease without the pathogen" is a simple one, excluding pathogens from production areas $\left(x_{\mathrm{O}}=0\right)$ can be difficult. When it is possible, exclusion is a most cost-effective disease management strategy.

The early detection and accurate identification of pathogens are often important first steps in exclusion, and the certification of pathogen-free status and safe movement of germplasm rely on their success $(66,101,113)$. All too frequently, pathogens move via human intervention. Quarantines can be an important first line of defense against their intended or unintended movement, and most countries have lists of forbidden or restricted pathogens and host plants $(66,88,113,143)$. Unfortunately, these rules are not always enforced sufficiently to ensure border safety, and there are numerous examples of destructive agents moving despite quarantines. The recent accidental introduction of Xanthomonas axonopodis pv. citri into citrus- growing areas in Florida and Queensland, Australia, and the purposeful movement of Moniliophthora perniciosa into cacao plantations in Bahia, Brazil, are good examples of the anthropogenic dissemination of harmful plant pathogens $(51,65,72,73)$. The removal of trade barriers may also be problematic; the concerns that nonendemic pathotypes of Guignardia musae and Ralstonia solanacearum might be introduced into Australia if Philippine bananas are shipped to this country are examples (70,113).

Pathogens that are moved in debris and on machinery, tools, and other implements can be excluded by surface disinfestation with chemical and physical measures (Fig. 10). Likewise, seed and planting material can be treated to kill pathogens. Heat treatment (thermotherapy) of vegetative propagation materials is useful against bacteria, fungi, nematode, and virus pathogens. However, there must be a significant difference between the temperatures at which a pathogen dies and the host is adversely affected. This can be a fine line, and heat- sensitive plants can be damaged if exacting temperature controls are not available. Only some pathogens lend themselves to this approach, and most of the successful examples that are available are for annual and/or temperate crops (101). However, heat treatment is effective for some tropical perennials. For example, heat treatment eliminates the ratoon stunt pathogen, Clavibacter xyli subsp. xyli, from sugarcane cuttings (50), and the burrowing nematode, Radopholus similis, from banana suckers (126).

Some pathogens can be eliminated from true seed, especially if contamination is restricted to the seed exterior. Although heat treatment is also used for this purpose (77), surface disinfestation with chlorine or fungicides is most frequent. For seedborne pathogens of quarantine concern, such as Fusarium oxysporum f. sp. elaeidis (Fusarium wilt of oil palm), extra precautions are needed to ensure that all seedborne inoculum is killed or intercepted (45). This has been of vital concern when oil palm seed from Africa has been disseminated. In
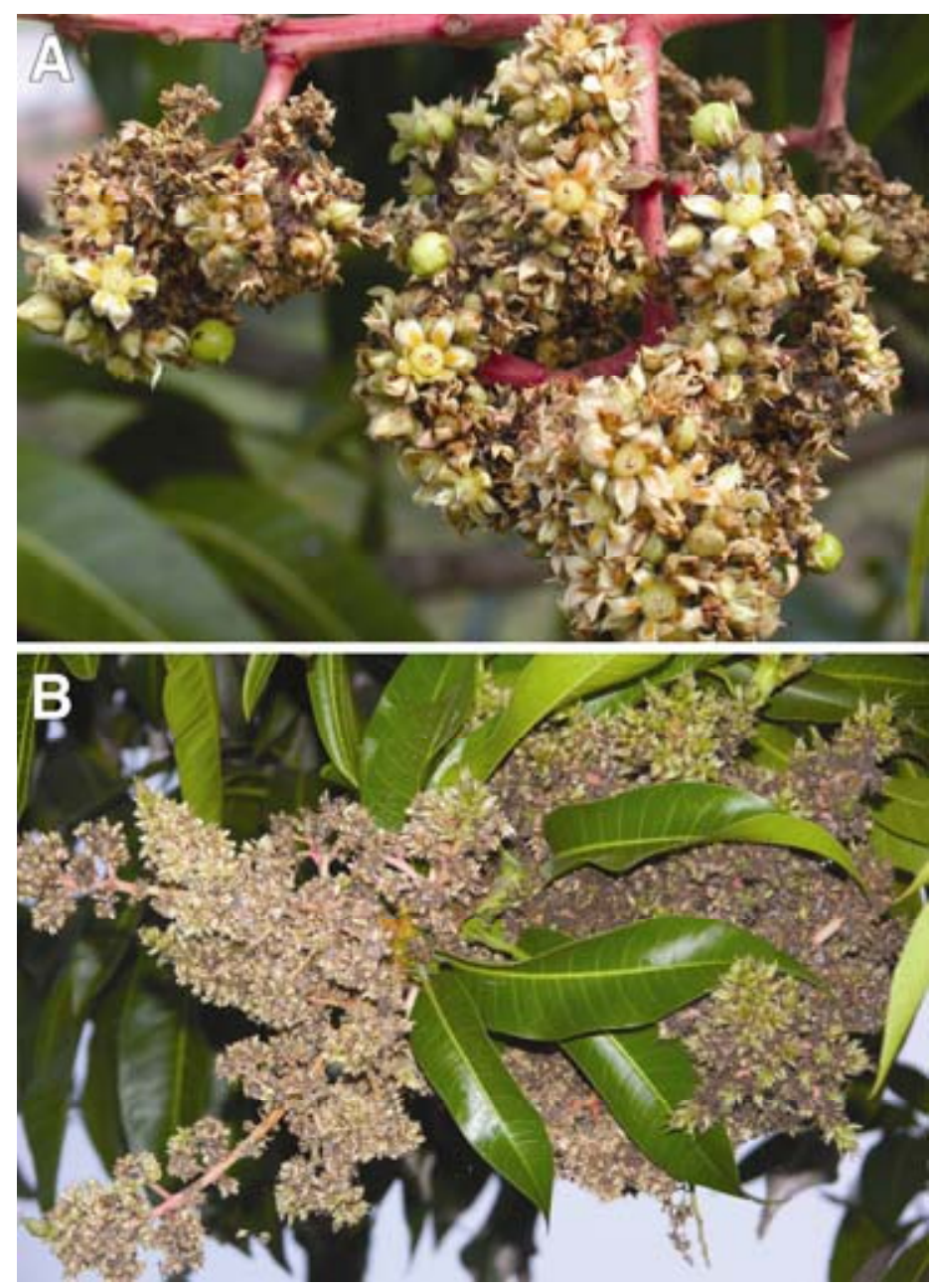

Fig. 5. Mango malformation is caused by several different fungi. In most of the world, including a presumed coevolved center in India, Fusarium mangiferae is responsible for the disease. However, in tropical America, F. sterilhyphosum, an unnamed mating population of the Gibberella fujikuroi species complex, and possibly other taxa cause and/or are associated with malformation. Note the similar panicle symptoms induced by A, F. mangiferae in Florida and B, Fusarium sp. in Mexico. 
these cases, seed have been vacuum infiltrated with fungicides and the resultant seedlings placed in intermediate (UK) and postentry (Malaysia) quarantine before release to breeding programs.

Pathogen vectors can also be eliminated to exclude pathogens of concern, but there are obvious requirements, including knowledge of which vectors are problematic, where they reside, and how and whether they can be managed effectively. As for the causal agents, complete elimination of vectors is often difficult.

Eradication. If pathogen exclusion has failed or is not possible, a different set of strategies is needed. These measures are diverse, always more expensive than pathogen exclusion, and seldom entirely effective. The recent investment of ca. \$1 billion to eradicate citrus canker in Florida is an extreme example of the expense of an unsuccessful effort to eliminate a pathogen (51; T. Gottwald, personal communication). Among these options, pathogen eradication is often considered first. Although the goal of eradication is to reduce $x_{\mathrm{O}}$ to 0 , in practice these measures are most often rate limiting.

When they are significant reservoirs of inoculum, alternate (i.e., hosts of heteroecious rusts) and alternative hosts are removed from plantations and destroyed. Disease pressure is usually reduced in such cases and, when alternative host species are involved, is most effective when their host ranges are limited. However, pathogens with wide host ranges can also be managed in this manner: for example, weed hosts of Cucumber mosaic virus in banana plantations (85). The effectiveness of removing alternate and alternative hosts depends on their size (is accomplished most readily when plants are small enough to be easily uprooted and removed) and the pathogen's mobility (the regional barberry eradication programs that were instituted to manage wheat stem rust is a prominent, albeit annual and nontropical, example of
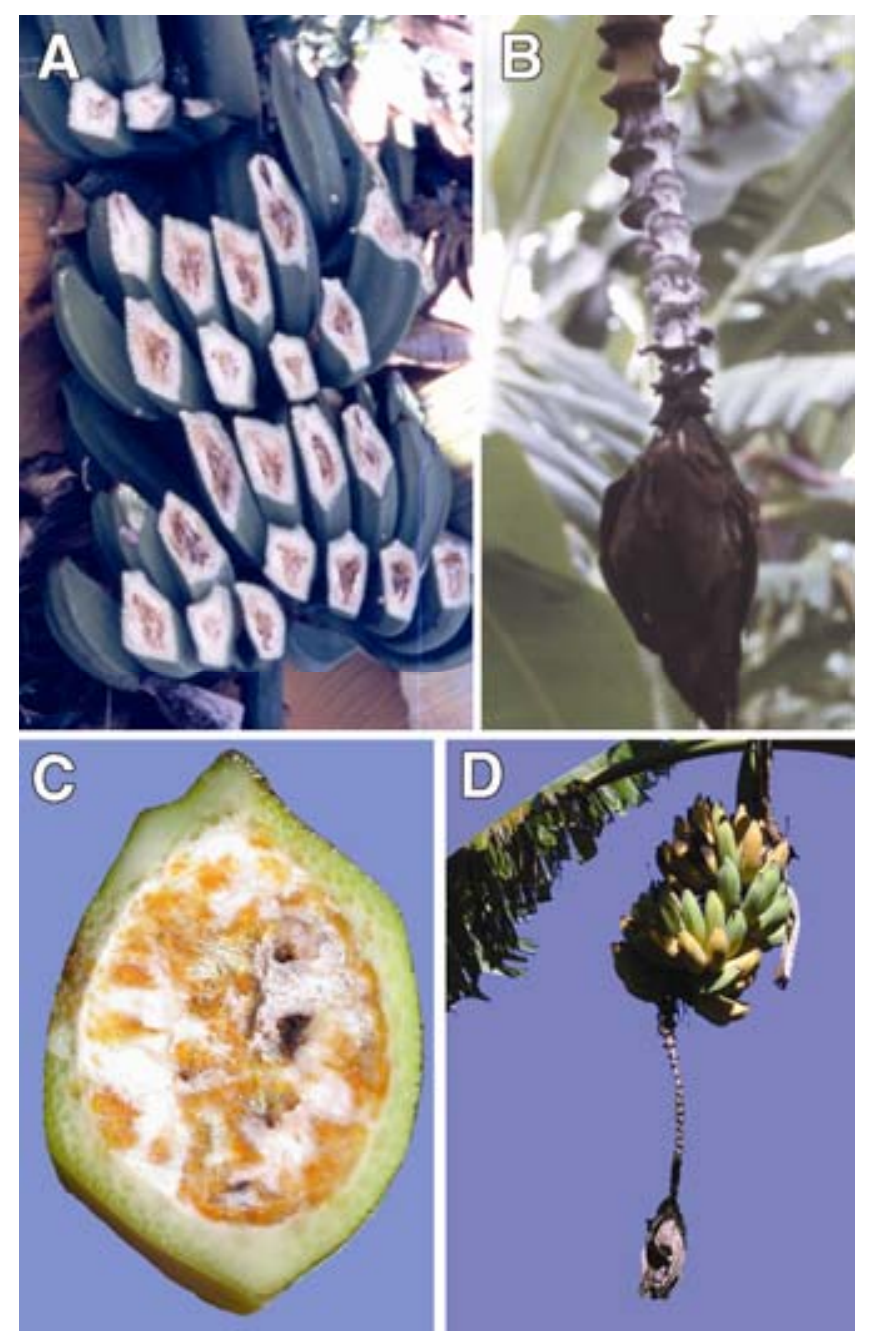

Fig. 6. Two new-encounter diseases of banana, A and B, Moko disease, caused by phylotype II of Ralstonia solanacearum, and C and D, xanthomonas bacterial wilt, caused by Xanthomonas campestris pv. musaearum, cause similar symptoms and have similar epidemiologies, despite their different geographic origins (respectively, tropical America and Ethiopia) and etiologies. Photos A and B courtesy of I. W. Buddenhagen, and C and D courtesy of Eric Boa. extreme measures that were used for a highly mobile pathogen on a widely dispersed alternate host [18]).

Sanitation, the removal of infested debris and host materials, is another common eradication strategy. As above, its impact depends upon the ease with which these reservoirs of inoculum can be removed from plantations. Roguing infected plants is a key strategy, especially if the crop plant is the primary or sole source of inoculum. For example, bunchy top of banana, caused by Banana bunchy top virus, can be managed only if affected plants are identified frequently (Fig. 11A), removed from plantations, and destroyed (Fig. 11B) (145). Successful control can also result

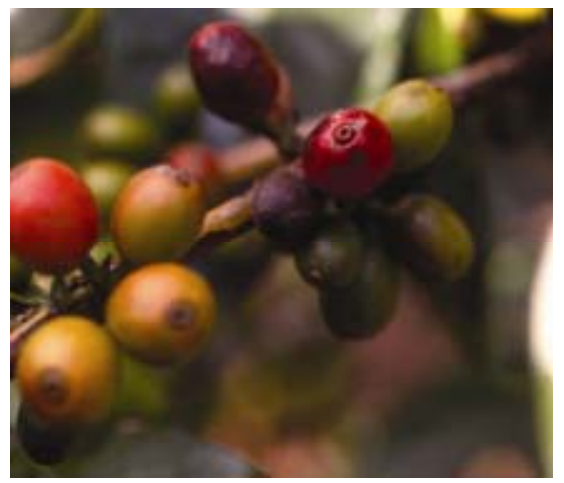

Fig. 7. Colletotrichum kahawae, cause of coffee berry disease, probably coevolved with a close relative of Coffea arabica, $C$. eugenioides.

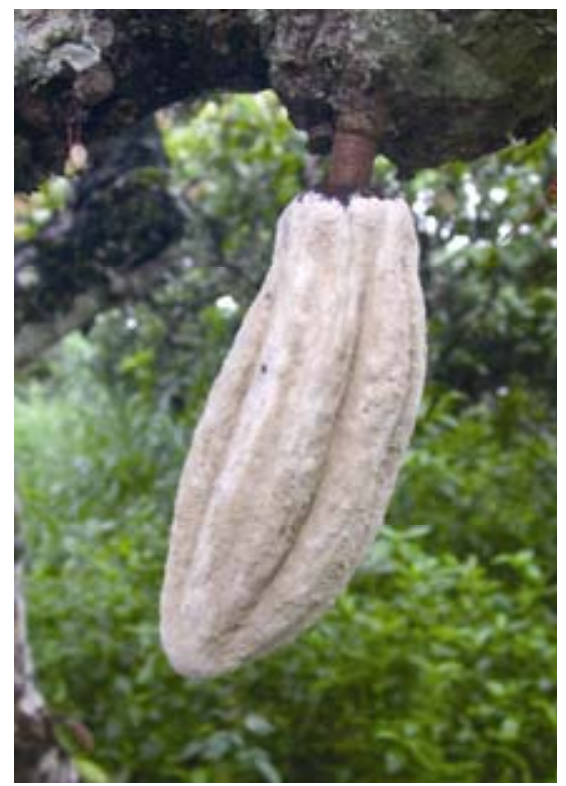

Fig. 8. The new-encounter disease frosty pod, caused by Moniliophthora rorei, is the most destructive disease of cacao, due in large part to the billions of thickwalled, long-lived infective spores that are produced on affected pods. Dissemination of frosty pod and witches'-broom (Fig. 2) to the important West African production areas would be disastrous for the world's chocolate trades. 
when specific organs of the host are removed. For example, the black pod and frosty pod diseases of cacao can be effectively and economically managed via the removal of affected pods (137). In contrast, root pathogens that have wide host ranges can be difficult to manage in this way since it is usually impossible to completely remove these host parts when preparing a site for planting. Armillaria spp., Ganoderma spp., Phellinus noxious, and Rigidoporus lignosus are among the most notorious examples of these pathogens because they are good saprophytes and colonize dead roots and stumps in disturbed sites $(99,107)$. Once affected materials are removed from plantations, it is important that they be destroyed (Fig. 11B). "Cull piles" are significant sources of inoculum for many diseases.

Different biocidal measures can be used to eliminate pathogens from soil. Their impacts range from nonspecific to somewhat specific, and due to their expense, they are used only for high-value crops. Flooding and broad-spectrum fumigants, such as methyl bromide + chloropicrin, eliminate large portions of the soil biota, resulting in what is essentially a biological vacuum. This can be a serious problem when the targeted pathogen has saprophytic capabilities. For example, formae speciales of Fusarium oxysporum rapidly recolonize treated soils since they are facultative saprophytes $(59,90,140)$. Other treatments such as steam and solarization have less dramatic effects and usually eliminate only temperature sensitive organisms (most plant pathogens are killed at the 60 to $70^{\circ} \mathrm{C}$ that is generated by steam or the recurring more moderate temperatures, 45 to $55^{\circ} \mathrm{C}$, that are generated in solarized soils) $(75,101)$. Most of these treatments, including fumigation, solarization, steam, and chemical drenches, affect only the surface horizons of soil. This can be a significant problem with pathogens that survive at lower depths.

Protection. Diverse chemical, physical, and biological measures can be used to protect tropical perennial hosts from diseases. Ultimately, these are all rate-limiting measures.

Protectant fungicides are among the most common disease-management tools in agriculture. In tropical perennials, they are used at all stages of production and are key in the management of foliar and fruit diseases; without them, many highvalue commodities could not be produced (102). Those that are highly susceptible to damaging diseases are among the most prominent examples; they include: banana (primarily Sigatoka leafspots), citrus (several fruit and foliar diseases), coffee (rust), and mango (primarily anthracnose) $(5,7,105,107,133)$.

Vector control can be used to indirectly protect the host from the pathogen, but there are several caveats. Pesticide applica- tions that are needed to effect disease control may not be cost effective unless the crop is valuable, the treatments are highly effective, and region-wide programs are utilized. The successful management of citrus greening in South Africa is a relevant example, in that large areas are treated for the psyllid vector (82). And even when these conditions are met, additional measures may be needed, such as the use of pathogen-free planting stock and the removal of alternative weed hosts of a pathogen. For diseases in which a single feeding event by the vector is sufficient to infect the host, effective host protection is impossible; papaya ringspot, which is caused by Papaya ringspot virus and vectored by transitory populations of aphids that do not establish on papaya (it is not a preferred host), is one such disease (103). Some vectors reside in protected locations that are relatively inaccessible to pesticides and thus are difficult to control. Examples include the phytophagous mango bud mite, Aceria mangiferae, which vectors Fusarium mangiferae and resides under leaf bud scales, and the banana aphid, Pentalonia nigronervosa, which vectors Banana bunchy top virus and lives at the bases of and underneath leaf sheaths (107). Finally, efficacious measures for controlling vectors may not

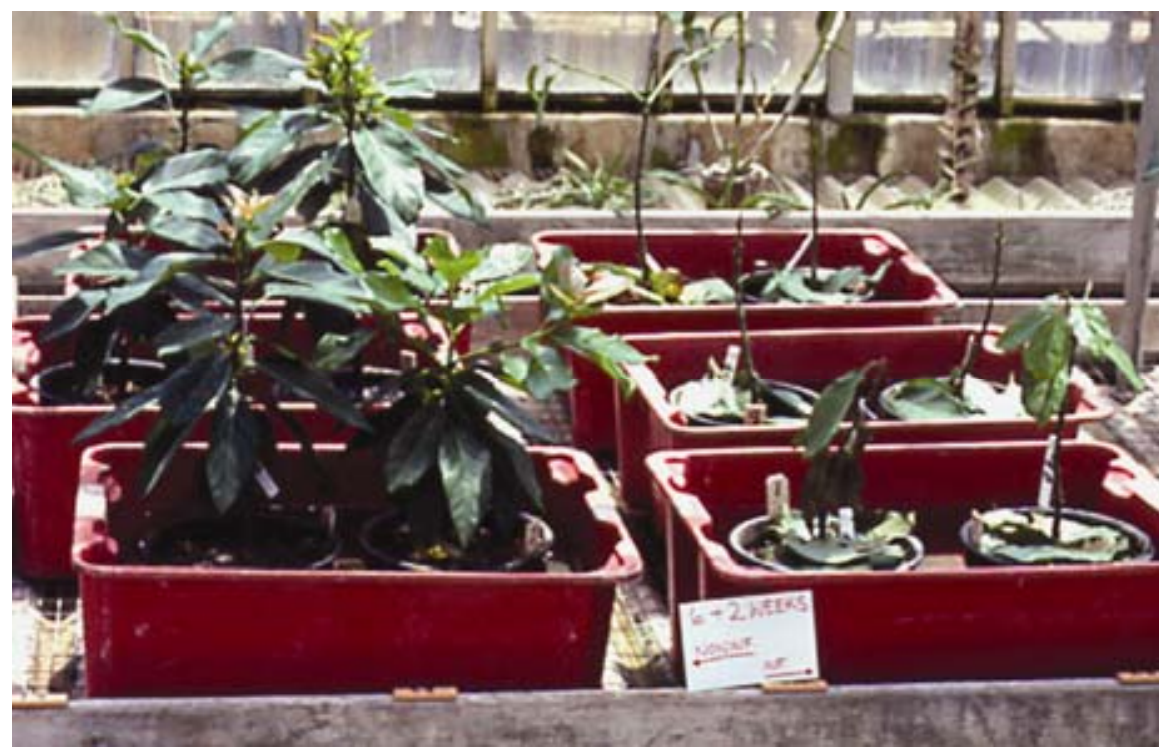

Fig. 9. Severity of Phytophthora root rot of avocado, caused by the new-encounter pathogen $P$. cinnamomi, is increased dramatically in flooded soil. These plants have been flooded for 2 weeks. Those on the left are in noninfested soil and those on the right are in soil infested with $P$. cinnamomi.

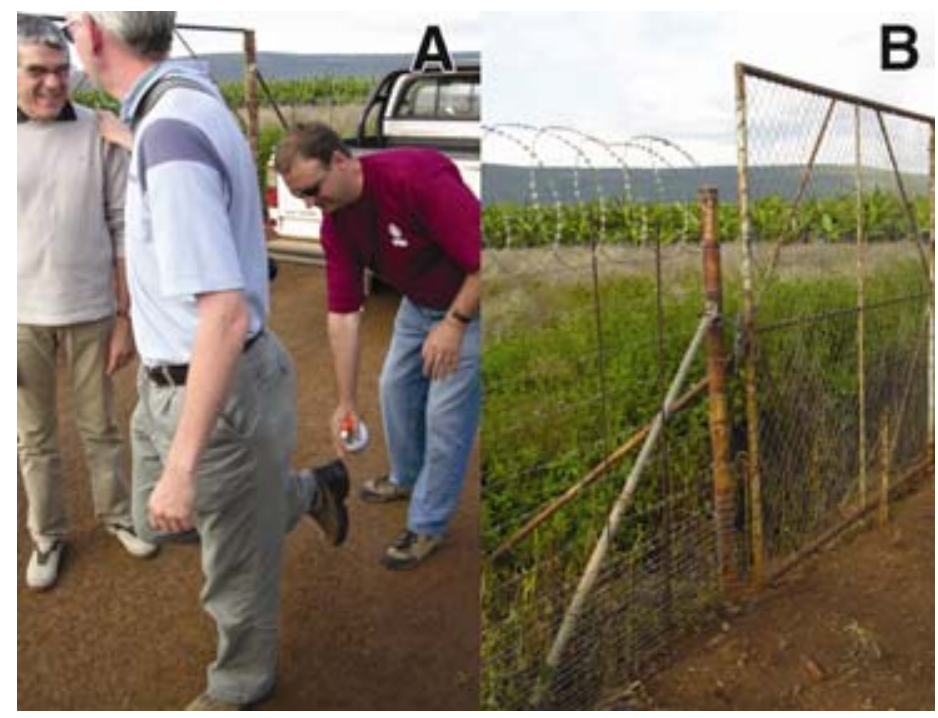

Fig. 10. Precautions against the movement of subtropical race 4 of Fusarium oxysporum f. sp. cubense in South Africa: A, Altus Viljoen disinfests the soles of Mike Rutherford's shoes before he moves from an infested area, and $B$, the pathogen is isolated in a former production area by a fence; note the fine-mesh barbed wire at the fence's base for small animals. 
be available. For example, papaya bunchy top was effectively managed with DDT, since it controlled the leafhopper vectors, Empoasca papayae and E. stevensi; however, an effective replacement for this insecticide has not been indentified (28).

Other issues that surround pesticide usage will not be covered here for lack of space, including: different chemistries that are available and their spectrums of activity; the development and use of disease forecasting models; application formulations, equipment, and methods; the use of spray oils, spreader stickers, and other amendments; applicator safety; and environmental concerns that are associated with pesticide usage (113).

Modifications of the producing environments are often useful. The density of plant cover/canopy has a pronounced effect on several diseases, although its impact varies depending upon the disease (101). Shade reduces the severity of black Sigatoka of banana, but it promotes the development of diseases that require high humidity or free moisture, such as black pod of cacao and coffee berry disease $(107,141,152)$. In the later cases, orienting rows such that prevailing winds and the morning sun have the greatest opportunity to dry the canopy can be helpful (111).

Diverse edaphic modifications are used. Improved drainage and the use of mounds or beds can significantly reduce stramenopile-induced root diseases $(22,39,95,147)$. Soil pH impacts many soilborne diseases. Acidic reactions generally favor Fusarium wilts and those caused by Rosellinia spp., whereas basic conditions favor diseases caused by Phymatotrichum omnivorum (101). Cultural practices may indirectly effect detrimental changes; for example, monoculture and the fertilizer that was used in Hawaiian pineapple production reduced soil $\mathrm{pH}$ and thereby favored Rotylenchus reniformis, a serious pathogen of this crop (14). Although it may be possible to change a soil's $\mathrm{pH}$ with amendments (e.g., lime to raise the $\mathrm{pH}$ of acidic soils or

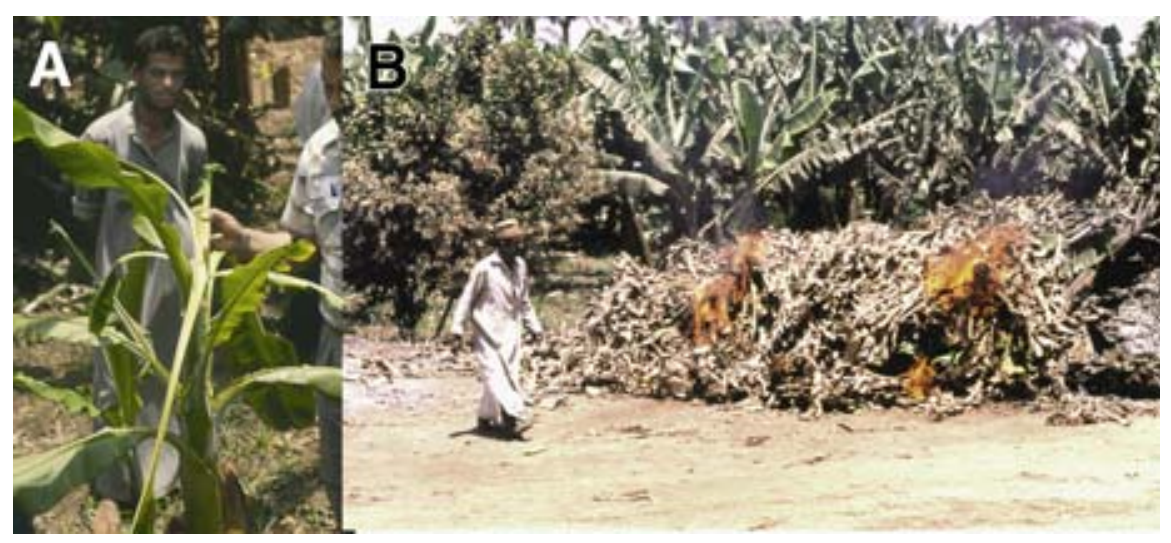

Fig. 11. The management of banana bunchy top, caused by Banana bunchy top virus, in Egypt and elsewhere relies on: A, frequently identifying symptomatic plants, and B, removing and destroying such plants. Banana cannot be grown successfully wherever this disease is found and these practices are not followed. studied extensively (69). The unique niches that are protected and the postharvest environmental control that is possible for many of these commodities have assisted the development of effective treatments, and commercial products exist that reduce disease to levels achieved by chemical measures $(69,78,79)$. Some virus-induced diseases have also been managed biologically, primarily with strains of the causal agents with attenuated virulence. For example, a nitrous acid-induced mutant of Papaya ringspot virus was used to cross-protect papaya plantings in Hawaii (163) in much the same way that mild strains of Citrus tristeza virus have been used to protect citrus (150).

Biological control of plant disease is never easy, and can be especially difficult for systemic diseases that increase in severity over the lifespan of a given planting. Research on the biological control of Panama disease illustrates the point with a crop that is typically grown for several years (108). Although numerous researchers have investigated the biological control of this disease, to date an $18 \%$ annual loss has been the best result achieved that has been reported in a refereed journal (127). This loss rate might be acceptable in a short-season crop, but would be disastrous in a perennial crop like banana (for example, a compounded loss of $63 \%$ would result after 5 years of ratoon production).

Resistance. Resistance to disease can be a formidable, rate-limiting tool in disease management. Genetic resistance obtained via conventional breeding has been responsible for some of the most important advances in production agriculture during the last century (136). For an interesting synopsis on disease resistance and breeding in tropical crops, see Buddenhagen (14).

The source and effectiveness of the genes that are used depend on whether the pathogen is a generalist (resistance to diseases they cause is usually poor) or hostspecialized. As mentioned above, resistance is often available for the coevolved, host-specialized diseases in the centers of origin (81,136). Many breeding success stories result from the use of such resistance.

Useful resistance may be available to some new-encounter diseases. For example, cacao parents that resist swollen shoot and vascular streak dieback are important in breeding programs in, respectively, Ghana and Papua New Guinea (R. J. Schnell, personal communication). However, useful genes may be infrequent in the new-encounter host crop. The poor resistance that exists in new-encounter situations can be circumvented if the original host of the new-encounter disease is sexually compatible with the new-encounter host. Intertaxon hybrids may be immediately useful. For example, interspecific hybrids between African oil palm, E. 
guineensis, and American oil palm, E. oleifera, resist two new-encounter diseases in the Western Hemisphere, bud rot and lethal wilt (12,31) (Fig. 12). Or resistance genes can be introgressed into the host crop. The late Phil Rowe's success in breeding disease-resistant banana hybrids relied on incorporating genes from disparate taxonomic backgrounds into hybrid diploids that were then used as pollen parents (121).

The need for and usefulness of resistant perennial crops in the tropics should consider the type of disease that is addressed.
Although they may be critical for foliar diseases that progress rapidly (high $r$ ), susceptible genotypes may be used for years before they need to be replaced if a slow-developing soilborne disease is involved. McDonald and Linde (93) classified the durability of host resistance based on the life strategies and niches of the causal agents.

Genetic resistance obtained via conventional breeding is often classified as vertical (usually controlled by one or a few major genes) or horizontal (several genes) $(93,154)$. Much has been written about the
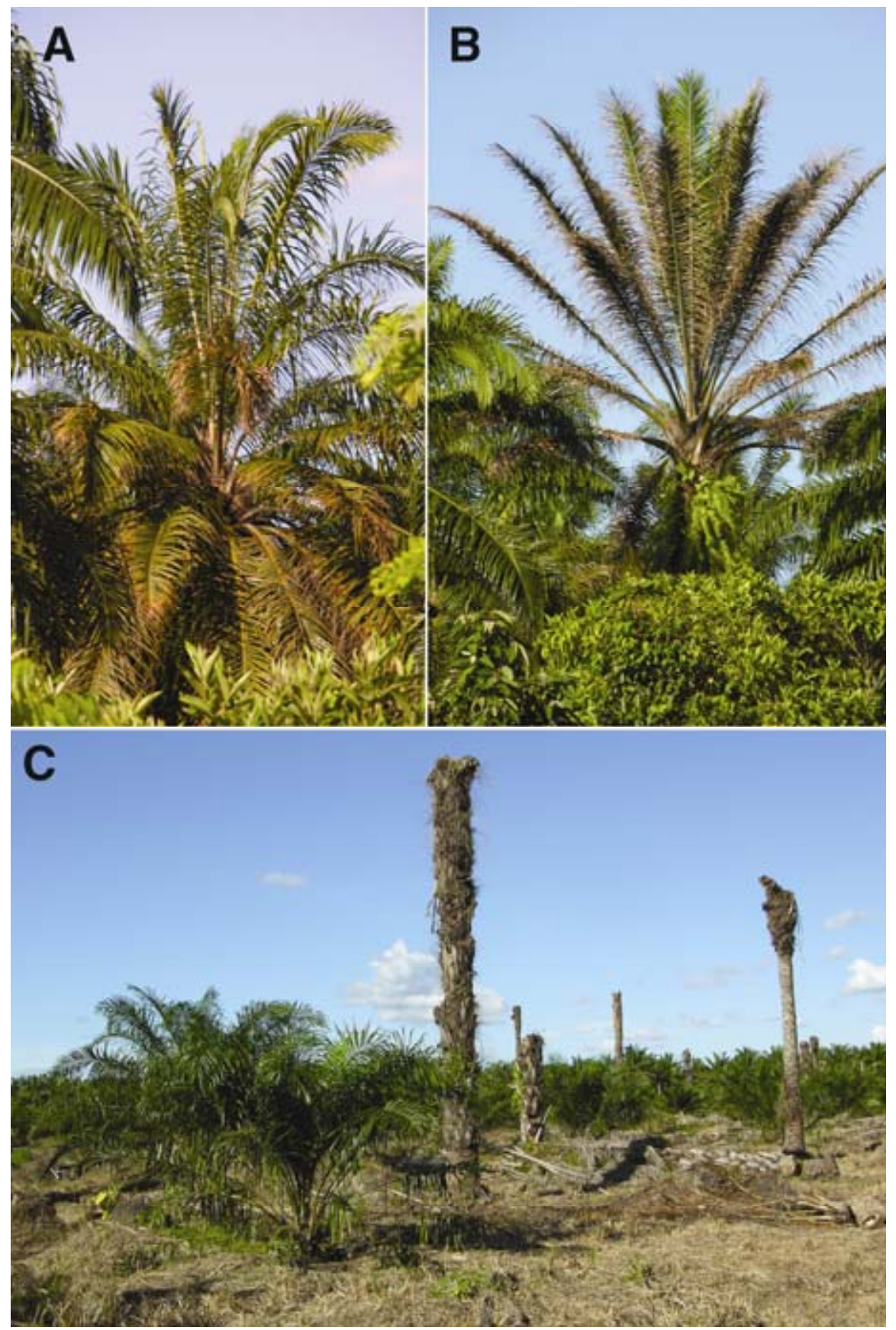

Fig. 12. The new-encounter disease lethal wilt (marchitez letal) rapidly kills oil palm in the Llanos region of Colombia. A and B, From the first stages of the disease until C, death, usually takes less than 6 months. Although its cause is not known, useful resistance is found in the American oil palm, Elaeis oleifera, which has been utilized in interspecific hybrids with E. guineensis (note that hybrids have been planted in the disease focus in C). dangers of vertical resistance. Although high levels of resistance can be achieved with it, it is almost always pathotype specific. Its use in perennial crops is dangerous since it can be easily overcome by the evolution or selection of virulent pathotypes. Coffee/Hemileia vastatrix and rubber/Microcylis ulei are two tropical perennial pathosystems for which vertical resistance has not been durable $(80,118$, 133,136).

The phenomenon of initial, excellent disease control that eventually erodes in vertically resistant hosts has been called the "boom-and-bust" cycle. It is most common with foliar diseases that have the potential for rapid epidemic development and are caused by genetically variable pathogens with both sexual and asexual life cycles, i.e., those classified by McDonald and Linde (93) as having "a high evolutionary potential." Although vertical resistance is usually not durable, it can be useful in some situations. For valuable crops in which good production (the "boom" part of the cycle) can be very profitable, long-term resistance may not be necessary. Acceptable production may be possible during the time that is needed to develop new resistant germplasm to combat the eventual, resistance-breaking pathotypes, especially when the pathogen has a low evolutionary potential $(93,136)$.

When considering horizontal resistance, disease impact must be taken into account. Horizontal resistance in perennial crops might be valuable against nonlethal diseases but less so against those that kill plants. Coffee improvement schemes have developed both vertical resistance to rust in C. arabica selections and hybrids as well as horizontal resistance in intra- and interspecific hybrids (the other parental species, C. canephora, is highly tolerant) $(118,133)$.

Genetic transformation for disease resistance (the creation of Genetically Modified Organisms, GMOs) can be quite effective $(93,143)$. Virus-induced diseases have lent themselves to this approach far more often than diseases caused by other pathogen groups, and there are some notable success stories. For example, the papaya industry in Hawaii was saved by selections that were genetically engineered for resistance to Papaya ringspot virus (44). In general, conventional materials are more accepted in the marketplace than are GMOs, especially in Europe. As consumers become better educated about the benefits and safety of GMOs, a greater acceptance of these products may occur.

Treatment of diseased plants. Diseased plants can be treated effectively with various curative (systemic) chemicals, and by the removal of affected portions of the host (i.e., surgery) to reduce inoculum levels. These are rate-limiting measures.

Since the development of the first systemic fungicides, an increasing number of these compounds have been developed for 
agricultural use. Benzimidazoles (1973), triazoles (1984), and strobilurins (1997) are among the most common systemic fungicides. Their primary activity is as protectants, but a portion of the applied compound is absorbed into treated organs. The curative, "kick-back" impact of these compounds revolutionized the management of many diseases (142).

An unfortunate attribute of some of the most effective systemic fungicides is the ease with which their efficacy is lost; their specific modes of action often make them vulnerable to the development of resistance. Black Sigatoka management in the Americas provides examples (105). Within 2 to 3 years of the introduction of benomyl for the control of black Sigatoka, resistance in $M$. fijiensis began to be observed

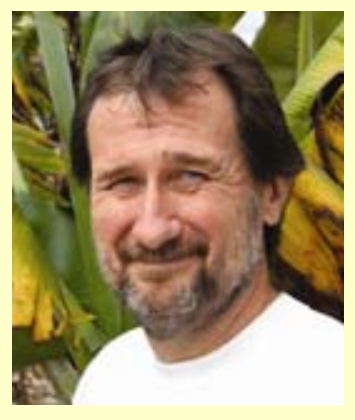

Randy C. Ploetz

Dr. Ploetz was born in Gastonia, $\mathrm{NC}$, where his father pitched for a minor league baseball team. Most of his boyhood was spent in the Midwest. He graduated from Purdue University in 1974 with a B.Sc. in forestry and in 1976 with an M.Sc. in plant pathology. In 1984, he received a Ph.D. in plant pathology from the University of Florida, and in 1986 he joined the faculty at the university's Tropical Research and Education Center. $\mathrm{He}$ was promoted to professor in 1996 and received the University of Florida Research Foundation Professor Award in 2004. His primary research responsibilities are on diseases of crops that are produced in South Florida, particularly tropical fruits. He has written/ edited four books and several hundred book chapters, refereed papers and technical publications. $\mathrm{He}$ is currently writing a twovolume book, Tropical Plant Pathology, for Springer-Verlag. He has served APS in diverse capacities including, Editor-in-Chief of APS Press and Director of the Office of International Programs. He now chairs an ad hoc committee that investigates APS's international activities. in Central America, and by the late 1970s the chemical could no longer be used effectively in many areas (142). More recently, strobilurins have become increasingly ineffective in tropical America against this disease $(68,105)$.

Brent and Hollomon (11) discussed the propensity of different classes of fungicides to lose effectiveness over time. They noted a wide range in the inherent risk of resistance to develop in different classes. Among the systemics that have been used against black Sigatoka, the benzimidazoles were ranked as high risk and the strobilurins as moderate. They also classified the risk of resistance developing in various pathosystems. The banana/M. fijiensis system was classified as high risk since the pathogen had a short generation time, sporulated abundantly, and had a sexual cycle that facilitated the development of resistance. Working groups of the Fungicide Resistance Action Committee (FRAC) of the Global Crop Protection Federation (an international consortium of agrochemical producers) have created use guidelines to prolong the effective life of vulnerable fungicides (11).

Two systemic pesticides, metalaxyl and fosetyl-Al (and its phosphonate derivatives), are effective against stramenopiles (23). Although metalaxyl is effective against a wider range of species than the phosphonates, it is more prone to the development of resistance and can also be microbially degraded in the soil, resulting in a rapid loss of activity $(95,107)$. Fosetyl$\mathrm{Al}$ and its active metabolite phosphorous acid are phloem, as well as xylem, mobile. This mobility enables effective concentrations of phosphonate metabolites to be translocated to above- and below-ground portions of plants when these compounds are trunk injected. Phytophthora root rot of avocado and $P$. palmivora-induced diseases of other tropical perennials are among the diseases that are managed effectively via trunk injection (35).

\section{Conclusions}

Ideally, crop production entails a holistic view of the health and productivity of a given crop. Disease management should be considered as part of an integrated approach to crop production that also includes the nutrition, water, and environmental needs of the crop, and its economic constraints.

Just as diverse facets of plant health should be considered during production, disease management should also embrace a holistic view. Diseases of tropical perennials that can be managed effectively with a single tool are rare, and in most cases an integrated approach should be considered that utilizes several different approaches. The integrated management of Phytophthora root rot of avocado is an excellent example of how the concerted use of hygiene and sanitation, cultural and biologi- cal controls, resistance, and pesticides could be used to manage a most difficult disease of a tropical perennial crop (22).

The management of diseases of tropical perennials is one of the greatest challenges in production agriculture. Long-term criteria must be used to judge the efficacy of the chosen strategies due in large part to the polycyclic nature of these diseases, the corresponding compound interest increase in disease that develops over time, and the disease-conducive environments that prevail in the tropics. Diverse factors that are mediated by time and money are far more critical for these problems than for those that face producers of other crops. Disease management strategies in tropical perennials must be effective and durable, yet responsive to changing environmental and market conditions. It is difficult to conceive of a more interesting and difficult set of problems in plant pathology.

\section{Acknowledgments}

I thank Ivan Buddenhagen and Harry Evans for helpful comments that improved this manuscript.

\section{Literature Cited}

1. Adams, F. G., Behrman, J. R., and Roldan, R A. 1979. Measuring the impact of primary commodity fluctuations on economic development: Coffee and Brazil. Am. Econ. Rev. 69:164-168.

2. Agrios, G. N. 2005. Plant Pathology. 5th ed. Elsevier, San Diego.

3. Al Adawi, A. O., Deadman, M. L., Al Rawahi, A. K., Al Maqbali, Y. M., Al Jahwari, A. A., Al Saadi, B. A., Al Amri, I. S., and Wingfield, M. J. 2006. Aetiology and causal agents of mango sudden decline disease in the Sultanate of Oman. Eur. J. Plant Pathol. 116:247-254.

4. Anonymous. 1979. Webster's New Twentieth Century Dictionary. 2nd ed. Simon \& Schuster, New York.

5. Arauz, L. F. 2000. Mango anthracnose: Economic impact and current options for integrated management. Plant Dis. 84:600-611.

6. Arnold, E. A., Zuleyka, M., Gilbert, G. S., Coley, P. D., and Kursar, T. A. 2000. Are tropical fungal endophytes hyperdiverse? Ecol. Lett. 3:267-274.

7. Avelino, J., Willocquet, L., and Savary, S. 2004. Effects of crop management patterns on coffee rust. Plant Pathol. 53:541-547.

8. Baker, C. J., Harrington, T. C., Krauss, U. and Alfenas, A. C. 2003. Genetic variability and host specialization in the Latin American clade of Ceratocystis fimbriata. Phytopathology 93:1274-1284

9. Bateson, M. F., Lines, R. E., Revill, P., Chaleeprom, W., Ha, C. V., Gibbs, A. J., and Dale, J. L. 2002. On the evolution and molecular epidemiology of the potyvirus Papaya ringspot virus. J. Gen. Virol. 83:2575-2585.

10. Bergelson, J., Dwyer, G., and Emerson, J. J. 2001. Models and data on plant-enemy coevolution. Annu. Rev. Genet. 35:469-499.

11. Brent, K. J., and Hollomon, D. W. 1998. Fungicide Resistance: The Assessment of Risk. FRAC Monogr. 2. Global Crop Protection Federation, Brussels.

12. Brücher, H. 1989. Useful Plants of Neotropical Origin. Springer Verlag, Berlin.

13. Buddenhagen, I. W. 1960. Strains of Pseudomonas solanacearum in indigenous hosts in banana plantations in Costa Rica, and their relationship to bacterial wilt of banana. Phy- 
topathology 50:660-664.

14. Buddenhagen, I. W. 1977. Resistance and vulnerability of tropical crops in relation to their evolution and breeding. Ann. N.Y. Acad. Sci. 287:309-326.

15. Burdon, J. J. 1993. The structure of pathogen populations in natural plant communities. Annu. Rev. Phytopathol. 31:305-323.

16. Burdon, J. J., and Thrall, P. H. 1999. Spatial and temporal patterns in coevolving plant and pathogen associations. Am. Natural. 153:S15S33.

17. Burdon, J. J., Thrall, P. H., and Ericson, L. 2006. The current and future dynamics of disease in plant communities. Annu. Rev. Phytopathol. 44:19-39.

18. Campbell, C. L., and Long, D. L. 2001. The campaign to eradicate the common barberry in the United States. Pages 16-50 in: Stem Rust of Wheat. From Ancient Enemy to Modern Foe. P. D. Peterson, ed. American Phytopathological Society, St. Paul, MN.

19. Cheesman, E. E. 1938. Notes on the nomenclature, classification and possible relationships of cacao populations. Trop. Agric. (Trinidad) 21:144-159.

20. Clay, K., and Kover, P. X. 1996. The Red Queen hypothesis and plant/pathogen interactions. Annu. Rev. Phytopathol. 34:29-50.

21. Clement, C. R. 1999. 1492 and the loss of Amazonian crop genetic resources. Econ. Bot. 53:188-202.

22. Coffey, M. D. 1987. Phytophthora root rot of avocado. An integrated approach to control in California. Plant Dis. 71:1046-1052.

23. Cohen, Y., and Coffey, M. D. 1986. Systemic fungicides and the control of oomycetes. Annu. Rev. Phytopathol. 24:311-338

24. Coutinho, T. A., Wingfield, M. J., Alfenas, A. C., and Crous, P. W. 1998. Eucalyptus rust: A disease with the potential for serious international implications. Plant Dis. 82:819-825.

25. Crute, I. R. 1998. The elucidation and exploitation of gene-for-gene recognition. Plant Pathol. 47:107-113.

26. Darwin, C. 1859. The Origin of Species by Means of Natural Selection. J. Murray, London.

27. Datnoff, L., Elmer, W. H., and Huber, D. M., eds. 2007. Mineral Nutrition and Plant Disease. American Phytopathological Society, St. Paul, MN.

28. Davis, M. J. 1994. Bunchy top. Pages 69-70 in: Compendium of Tropical Fruit Diseases. R. C. Ploetz, G. A. Zentmyer, W. T. Nishijima, K. G. Rohrbach, and H. D. Ohr, eds. American Phytopathological Society, St. Paul, MN

29. Davis, M. J., Ying, Z., Brunner, B., Pantoja, A., and Ferwerda, F. H. 1998. Rickettsial relative associated with papaya bunchy top disease. Curr. Microbiol. 36:80-84.

30. Davis, W. 1996. One River: Explorations and Discoveries in the Amazon River Forest. Simon \& Schuster, New York.

31. de Franqueville, H. 2003. Oil palm bud rot in Latin America. Exp. Agric. 39:225-240.

32. Denham, T. P., Haberle, S. G., Lentfer, C., Fullagar, R., Field, J., Therin, M., Porch, N., and Winsborough, B. 2003. Origins of Agriculture at Kuk Swamp in the Highlands of New Guinea. Science 301:189-193.

33. Diamond, J. 1997. Guns, Germs, and Steel. Norton, New York.

34. Doebley, J. 2004. The genetics of maize evolution. Annu. Rev. Genet. 38:37-59.

35. Drenth, A., and Guest, D. I., eds. 2004. Diversity and management of Phytophthora in Southeast Asia. ACIAR Monogr. 114.

36. Durand-Gasselin, T., Asmady, H., Flori, A., Jacquemard, J. C., Hayun, Z., Breton, F., and de Franqueville, H. 2005. Possible sources of resistance in oil palm (Elaeis guineensis Jacq.) to basal stem rot caused by Ganoderma boninense - prospects for future breeding. Mycopathologia 159:93-100.

37. Engelbrecht, C. J. B., and Harrington, T. C. 2005. Intersterility, morphology, and taxonomy of Ceratocystis fimbriata on sweet potato, cacao, and sycamore. Mycologia 97:5769.

38. Erlich, P. R., and Raven, P. H. 1964 Butterflies and plants: A study in coevolution. Evolution 18:586-608.

39. Erwin, D. C., and Ribeiro, O. K. 1996. Phytophthora Diseases Worldwide. American Phytopathological Society, St. Paul, MN.

40. Evans, H. C. 2002. Invasive Neotropical Pathogens of Tree Crops. Pages 83-112 in: Tropical Mycology: Vol. 2, Micromycetes. CABI Publishing, Wallingford, Oxon, UK.

41. Evans, H. C. Cacao Diseases - The Trilogy Revisited. Phytopathology. In press.

42. FAO online database. 2006. Food and Agricultural Organization of the United Nations, Rome.

43. Fegan, M., and Prior, P. 2006. Diverse members of the Ralstonia solanacearum species complex cause bacterial wilts of banana. Australas. Plant Pathol. 35:93-101.

44. Ferreira, S. A., Pitz, K. Y., Manshardt, R., Zee, F., Fitch, M., and Gonsalves, D. 2002. Virus coat protein transgenic papaya provides practical control of Papaya ringspot virus in Hawaii. Plant Dis. 86:101-105.

45. Flood, J. 2006. A review of Fusarium wilt of oil palm caused by Fusarium oxysporum f. sp. elaeidis. Phytopathology 96:660-662.

46. Flor, H. H. 1955. Host-parasite interaction in flax rust - its genetics and other implications. Phytopathology 45:680-685.

47. Fullerton, R. A., and Olsen, T. L. 1995. Pathogenic variability in Mycosphaerella fijiensis Moelet, cause of black Sigatoka in banana and plantain. N.Z. J. Hortic. Sci. 23:3948.

48. Gagnevin, L., and Pruvost, O. 2001. Epidemiology and control of mango bacterial black spot. Plant Dis. 85:928-935.

49. Garrett, K. A., and Mundt, C. C. 1999. Epidemiology in mixed host populations. Phytopathology 89:984-990.

50. Gillaspie, A. G., Jr., and Davis, M. J. 1992. Ratoon stunting of sugarcane. Pages 41-61 in: Plant Diseases of International Importance. Vol. IV. Diseases of Sugar, Forest, and Plantation Crops. A. N. Mukhopadhyay, J. Kumar, H. S. Chaube, and U. S. Singh, eds. Prentice Hall, Engelwood Cliffs, NJ.

51. Gottwald, T. R., Graham, J. H., and Schubert, J. S. 2002. Citrus canker: The pathogen and its impact. Online publication. Plant Health Prog. doi:10.1094/PHP-2002-0812-01-RV.

52. Guest, D. 2007. Vascular-streak dieback: A new encounter disease caused by the obligate basidiomycete Oncobasidium theobromae. Phytopathology. In press.

53. Haldane, J. B. S. 1949. Disease and evolution. La Ric. Sci. Suppl. 19:68-76.

54. Hallett, S. G. 2006. Dislocation from coevolved relationships: A unifying theory for plant invasion and natuarlization. Weed Sci. 54:282-290.

55. Hammond, R. W. and Owens, R. A. 2006. Viroids: New and continuing risks for horticultural and agricultural crops. APSnet feature article. October 2006. American Phytopathological Society, St. Paul, MN. Online publication.

56. Harlan, J. R. 1971. Agricultural origins: Centers and noncenters. Science 174:468-474

57. Harlan, J. R. 1976. Diseases as a factor in plant evolution. Annu. Rev. Phytopathol. $14: 31-51$

58. Harrison, N. A., and Jones, P. 2003. Diseases of coconut. Pages 197-225 in: Diseases of Tropical Fruit Crops. CAB International, Wallingford, Oxon, UK
59. Herbert, J. A., and Marx, D. 1990. Short-term control of Panama disease of bananas in South Africa. Phytophylactica 22:339-340.

60. Hill, D. S., and Waller, J. M. 1982. Pests and Diseases of Tropical Crops. Longman, London.

61. Hillebrand, H. 2004. On the generality of the latitudinal diversity gradient. Am. Natural. 163:192-211.

62. Holst-Jensen, A., Kohn, L. M., Jakobsen, K. S., and Schumacher, T. 1997. Molecular phylogeny and evolution of Monilinia (Sclerotiniaceae) based on coding and noncoding rDNA sequences. Am. J. Bot. 84:686-701.

63. Humboldt, A. 1808. Ansichten der Natur miy wissenschaftlichen Erlauterungen. J. G. Cotta, Tübingen, Germany.

64. Husband, R., Herre, E. A., Turner, S. L., Gallery, R., and Young, J. P. W. 2002. Molecular diversity of arbuscular mycorrhizal fungi and patterns of host association over time and space in a tropical forest. Mol. Ecol. 11:26692678

65. International Phytosanitary Portal. Detection of Citrus Canker in geographically isolated area - Queensland - Australia. Online publication. Intl. Plant Prot. Convention.

66. International Plant Genetic Resources Institute. Guidelines for the safe movement of plant germplasm. (Several publications with different publication dates) Food and Agricultural Organization of the United Nations, Rome.

67. Jablonski, D., Roy, K., and Valentine, J. W 2006. Out of the tropics: Evolutionary dynamics of the latitudinal diversity gradient. Science 314:102-106.

68. Jacome, L., Lepoivre, P., Marin, D., Ortiz, R., Romero, R., and Escalant, J. V., eds. 2002. Mycosphaerella Leaf Spot Diseases of $\mathrm{Ba}-$ nana: Present Status and Outlook. International Network for the Improvement of Banana and Plantain (Bioversity International).

69. Janisiewicz, W. J., and Korsten, L. 2002. Biological control of postharvest diseases of fruits. Annu. Rev. Phytopathol. 40:411-441.

70. Jones, D. R., ed. 2000. Diseases of Banana Abaca and Enset. CAB International, Wallingford, Oxon, UK.

71. Jones, D. R. 2000. Introduction to banana, abaca and enset. Pages 1-36 in: Diseases of Banana, Abaca and Enset. CAB International, Wallingford, Oxon, UK.

72. Junior, P. 2006. A caça ás bruxas. Veja (Brazilian periodical) 5 July. pp. 52-53.

73. Junior, P. 2006. Terrorismo biològico. Veja (Brazilian periodical) 21 July. pp. 60-63.

74. Kareiva, P. 1999. Coevolutionary arms races: Is victory possible? Proc. Natl. Acad. Sci (USA) 96:8-10.

75. Katan, J. 1987. Soil solarization. Pages 77105 in: Innovative Approaches to Plant Disease Control. I. Chet, ed. John Wiley \& Sons, New York.

76. Kislev, M. E., Hartmann, A., and Bar-Yosef, O. 2006. Early domestication of fig in the Jordan Valley. Science 312:1372-1374.

77. Klotz, L. J., DeWolfe, T. A., Roistacher, C N., Nauer, E. M., and Carpenter, J. B. 1960. Heat treatments destroy fungi in infected seeds and seedlings of citrus. Plant Dis. Rep. 44:858-861.

78. Korsten, L., De Jager, E. S., De Villers, E. E., Lourens, A., Kotzé, J. M., and Wehner, F. C. 1995. Evaluation of bacterial epiphytes isolated from avocado leaf and fruit surfaces for biocontrol of avocado postharvest disease. Plant Dis. 79:1149-1156.

79. Korsten, L., De Villiers, E. E., Wehner, F. C., and Kotzé, J. M. 1997. Field sprays of Bacillus subtilis and fungicides for control of preharvest fruit diseases of avocado in South Africa. Plant Dis. 81:455-459. 
80. Le Guen, V., Garcia, D., Mattos, C. R. R., Doaré, F., Lespinasse, D., and Seguin, M. 2007. Bypassing of a polygenic Microcyclus ulei resistance in rubber tree, analyzed by QTL detection. New Phytol. 173:335-345.

81. Leppik, E. E. 1970. Gene centers of plants as sources of disease resistance. Annu. Rev. Phytopathol. 8:323-344.

82. Le Roux, H. F., van Vuuren, S. P., Pretorius, M. C., and Buitendag, C. H. 2006. Management of Huanglongbing in South Africa. Huanglongbing Greening Workshop International. Ribeirao Preto, S. P. Brazil. 16-20 July, 2006. pp. 43-47.

83. Lim, T.-K., and Manicom, B. Q. 2003. Diseases of guava. Pages 275-289 in: Diseases of Tropical Fruit Crops. CAB International, Wallingford, Oxon, UK

84. Lockhart, B. E. 2001. Badnaviruses. Pages 99-101 in: Encyclopedia of Plant Pathology. O. C. Maloy and T. D. Murray, eds. John Wiley \& Sons, New York.

85. Lockhart, B. E. L., and Jones, D. R. 2000. Banana mosaic. Pages 256-263 in: Diseases of Banana, Abaca and Enset. CAB International, Wallingford, Oxon, UK

86. Lodge, D. J. 1997. Factors relating to diversity of decomposer fungi in tropical forests. Biodivers. Conserv. 6:681-688.

87. Lodge, D. J., Hawksworth, D. L., and Ritchie, B. J. 1996. Microbial diversity and tropical forest functioning. Ecol. Stud. 122:69-100.

88. Madden, L. W. 2001. What are the nonindigenous plant pathogens that threaten U.S. crops and forests? APSnet feature story. American Phytopathological Society, St. Paul, MN. Online publication.

89. Marasas, W. F. O., Ploetz, R. C., Wingfield, M. J., Wingfield, B. D., and Steenkamp, E. T. 2006. Mango malformation disease and the associated Fusarium species. Phytopathology 96:667-672.

90. Marois, J. J., Dunn, M. T., and Papavizas, G. C. 1983. Reinvasion of fumigated soil by Fusarium oxysporum f. sp. melonis. Phytopathology 73:680-684

91. Martin, F. W., Campbell, C. W., and Ruberte, R. M. 1987. Perennial Edible Fruits of the Tropics. An Inventory. U.S. Dep. Agric. Agric. Res. Serv. Agric. Handb. No. 642.

92. McCook, S. 2006. Global rust belt: Hemileia vastatrix and the ecological integration of world coffee production since 1850. J. Global Hist. 1:177-195.

93. McDonald, B. A., and Linde, C. 2002. Pathogen genetics, evoutionary potential, and durable resistance. Annu. Rev. Phytopathol. 40:349-379

94. Menge, J. A., and Nemec, S. 1997. Citrus. Pages 185-227 in: Soilborne Diseases of Tropical Crops. CAB International, Wallingford, Oxon, UK.

95. Menge, J. A., and Ploetz, R. C. 2003. Diseases of avocado. Pages 35-71 in: Diseases of Tropical Fruit Crops. CAB International, Wallingford, Oxon, UK

96. Mitchell, C. E., Agrawal, A. A., Bever, J. D., Gilbert, G. S., Hufbauer, R. A., Klironomos, J. N., Maron, J. L., Morris, W. F., Parker, I. M., Power, A. G., Seabloom, E. W., Torchin, M. E., and Vázquez, D. P. 2006. Biotic interactions and plant invasions. Ecol. Lett. 9:726-740.

97. Mitchell, C. E., and Power, A. G. 2003. Release of invasive plants from fungal and viral pathogens. Nature 421:625-627.

98. Mundt, C. C. 2002. Use of multiline cultivars and cultivar mixtures for disease management. Annu. Rev. Phytopathol. 40:381-410.

99. Nandris, D., Nicole, M., and Geiger, J. P. 1987. Root rot diseases of rubber trees. Plant Dis. 71:298-306.

100. Nolla, J. A. B., and Fernandez Valiela, M. V. 1976. Contributions to the history of plant pa- thology in South America, Central America, and Mexico. Annu. Rev. Phytopathol. 14:11-29.

101. Palti, J. 1981. Cultural Practices and Infectious Crop Diseases. Springer-Verlag, Berlin.

102. Parker, I. M., and Gilbert, G. S. 2004. The evolutionary ecology of novel plant-pathogen interactions. Annu. Rev. Ecol. Evol. Syst. 35:675-700.

103. Perseley, D. M., and Ploetz, R. C. 2003. Diseases of papaya. Pages 373-412 in: Diseases of Tropical Fruit Crops. CAB International, Wallingford, Oxon, UK

104. Pilotti, C. A. 2005. Stem rots of oil palm caused by Ganoderma boninense: Pathogen biology and epidemiology. Mycopathologia 159:129-137.

105. Ploetz, R. C. 2000. Management of the most important disease of banana and plantain, black Sigatoka. Pest. Outl. 11:19-23.

106. Ploetz, R. C. 2003. Diseases of mango. Pages 327-363 in: Diseases of Tropical Fruit Crops. CAB International, Wallingford, Oxon, UK.

107. Ploetz, R. C., ed. 2003. Diseases of Tropical Fruit Crops. CAB International, Wallingford, Oxon, UK.

108. Ploetz, R. C. 2004. Biological control of Fusarium wilt: A review and an evaluation. Page 141 in: Abstract Booklet, International Congress on Musa: Harnessing Research to Improve Livelihoods. INIBAP (Bioversity International) Online publication.

109. Ploetz, R. C. 2006. Fusarium-induced diseases of tropical, perennial crops. Phytopathology 96:648-652.

110. Ploetz, R. C. 2006. Fusarium wilt of banana is caused by several pathogens referred to as F. oxysporum f. sp. cubense. Phytopathology 96:653-656

111. Ploetz, R. C. Cacao diseases: Important threats to chocolate production worldwide. Phytopathology In press

112. Ploetz, R. C., Benscher, D., Dorey, A. J., and Vázquez, A. 2000. The epidemiology, control and cause of sooty blotch of carambola, Averrhoa carambola L., in South Florida. Fruits 55:241-252.

113. Ploetz, R. C., and Pegg, K. G. 1997. Fusarium wilt of banana and Wallace's line: Was the disease originally restricted to his IndoMalayan region? Australas. Plant Pathol. 26:239-249.

114. Ploetz, R. C., Timmer, L. W., and Garnsey, S. M 2003. Management of tropical fruit diseases: Current overview and future outlook. Pages 465-481 in: Diseases of Tropical Fruit Crops. CAB International, Wallingford, Oxon, UK.

115. Purseglove, J. W. 1972. Tropical Crops. Dicots. Longman, London.

116. Qin, X., Miranda, V. S., Machado, M. A., Lemos, E. G. M., and Hartung, J. S. 2001. An evaluation of the genetic diversity of Xylella fastidiosa isolated from diseased citrus and coffee in São Paulo, Brazil. Phytopathology 91:599-605.

117. Robinson, R. A. 1976. Plant Pathosystems. Springer-Verlag, New York.

118. Rodrigues, C. J., Jr., Bettencourt, A. J., and Rijo, L. 1976. Races of the pathogen and resistance to coffee rust. Annu. Rev. Phytopathol. 13:49-70.

119. Rodriguez-Alvarado, G., Fernández-Pavía, S. P., and Ploetz, R. C. 2006. Fusarium sp. characterization causing mango malformation in Michoacan Mexico. (Abstr.) Phytopathology 96:S99.

120. Romero, R. A., and Sutton, T. B. 1997. Sensitivity of Mycosphaerella fijiensis, causal agent of black Sigatoka of banana, to propiconazole. Phytopathology 87:96-100.

21. Rowe, P. R., and Rosales, F. E. 2000. Conventional banana breeding in Honduras. Pages 435-449 in: Diseases of Banana, Abaca and Enset. CAB International, Wallingford, Oxon,
UK.

122. Roy, B. A. 2001. Patterns of association between crucifers and their flower-mimic pathogens: Host jumps are more common than coevolution or cospeciation. Evolution 55:41-53.

123. Rutherford, M. A. 2006. Current knowledge of coffee wilt disease, a major constraint to coffee production in Africa. Phytopathology 96:663-666

124. Samuels, G. J., Pardo-Schultheiss, R., Hebbar, K. P., Lumsden, R. D., Bastos, C. N., Costa, J. C., and Bezzera, J. L. 2000. Trichoderma stromaticum sp. nov., a parasite of the cacao witches broom pathogen. Mycol. Res. 104:760-764.

125. Sanogo, S., Pomella, A., Hebbar, P. K., Bailey, B., Costa, J. C. B., Samuels, G. J., an Lumsden, R. D. 2002. Production and germination of conidia of Trichoderma stromaticum, a mycoparasite of Crinipellis perniciosa on cacao. Phytopathology 92:1032-1037.

126. Sarah, J.-L. 2000. Burrowing nematode. Pages 295-303 in: Diseases of Banana, Abaca and Enset. CAB International, Wallingford Oxon, UK

127. Saravanan, T., Muthusamy, M., and Marimuthu, T. 2003. Development of integrated approach to manage the fusarial wilt of banana. Crop Prot. 22:1117-1123.

128. Sauer, J. D. 1993. Historical Geography of Crop Plants. A Select Roster. CRC Press, Boca Raton, FL.

129. Schardl, C. L., Leuchtmann, A., and Chung, K.-R. 1997. Coevolution by common descent of fungal symbionts (Epichlö̈ spp.) and grass hosts. Mol. Biol. Evol. 14:133-143.

130. Schieber, E. 1972. Economic impact of coffee rust in Latin America. Annu. Rev. Phytopathol. 10:491-510.

131. Schoeneweiss, D. F. 1975. Predisposition, stress and plant disease. Annu. Rev. Phytopathol. 13:193-211.

132. Sequeira, L. 1962. Special contributions from the tropics to phytopathological mycology. Phytopathology 52:936-942.

133. Silva, M. C., Várzea, V., Guerra-Guimarães, L., Azinheira, H. G., Fernandez, D., Petitot, A.-S., Bertrand, B., Lashermes, P., and Nicole, M. 2006. Coffee resistance to the main diseases: Leaf rust and coffee berry disease. Braz. J. Plant Physiol. 18:119-147.

134. Simmonds, N. W. 1962. The Evolution of the Bananas. Longman, London.

135. Simmonds, N. W. 1976. Evolution of Crop Plants. Longman, London.

136. Simmonds, N. W., and Smartt, J. 1999. Principles of Crop Improvement. Blackwell Science, Oxford.

137. Soberanis, W., Ríos, R., Arévalo, E., Zúñiga, L., Cabezas, O., and Krauss, U. 1999. Increased frequency of phytosanitary pod removal in cacao (Theobroma cacao) increases yield economically in eastern Peru. Crop Prot. 18:677-685.

138. Staats, M., van Baarlen, P., and van Kan, J. A. L. 2005. Molecular phylogeny of the plant pathogenic genus Botrytis and the evolution of host specity. Mol. Biol. Evol. 22:333-346.

139. Stevens, P. F. 2003. Angiosperm Phylogeny Website. University of Missouri, St Louis, and Missouri Botanical Garden. Online publication.

140. Stover, R. H. 1962. Fusarial Wilt (Panama Disease) of Bananas and other Musa species. Commonwealth Mycological Institute, Kew, Surrey, UK.

141. Stover, R. H. 1972. Banana, Plantain and Abaca Diseases. Commonwealth Mycological Institute, Kew, Surrey, UK.

142. Stover, R. H. 1990. Sigatoka leaf spots: Thirty years of changing control strategies: 19591989. Pages 66-74 in: Sigatoka Leaf Spot Diseases of Banana. R. A. Fullerton and R. H. 
Stover, eds. INIBAP, Montpellier, France.

143. Strange, R. N., and Scott, P. R. 2005. Plant disease: A threat to global food security. Annu. Rev. Phytopathol. 43:83-116.

144. Tano, K., and Willcox, G. 2006. How fast was wild wheat domesticated? Science 311:1886.

145. Thomas, J. E., and Iskra-Caruana, M. L. 2000. Bunchy top. Pages 241-253 in: Diseases of Banana, Abaca and Enset. CAB International, Wallingford, Oxon, UK.

146. Thompson, J. N. 1999. Specific hypotheses on the geographic mosaic of coevolution. Am. Natural. 153:S1-S14.

147. Thurston, H. D. 1992. Sustainable Practices for Plant Disease Management in Traditional Farming Systems. Westview Press, Boulder, CO.

148. Thurston, H. D. 1998. Tropical Plant Diseases. 2nd ed. American Phytopathological Society, St. Paul, MN.

149. Thwaites, R., Eden-Green, S. J., and Black, R. 2000. Diseases caused by bacteria. Pages 213-239 in: Diseases of Banana, Abaca and Enset. CAB International, Wallingford, Oxon, UK.

150. Timmer, L. W., Garnsey, S. M., and Broadbent, P. 2003. Diseases of citrus. Pages 163195 in: Diseases of Tropical Fruit Crops. CAB International, Wallingford, Oxon, UK.

151. Tushemereirwe, W., Kangire, A., Ssekiwoko,
F., Offord, L. C., Crozier, J., Boa, E., Rutherford, M., and Smith, J. J. 2004. First report of Xanthomonas campestris pv. musacearum on banana in Uganda. Plant Pathol. 53:802.

152. van der Graaff, N. A. 1992. Coffee berry disease. Pages 202-230 in: Plant Diseases of International Importance. Vol. IV. Diseases of Sugar, Forest, and Plantation Crops. A. N. Mukhopadhyay, J. Kumar, H. S. Chaube, and U. S. Singh, eds. Prentice Hall. Engelwood Cliffs, NJ.

153. van der Plaats-Niterink, A. J. 1981. Monograph of the Genus Pythium. Centraalbureau voor Schimmelcultures.

154. van der Plank, J. E. 1963. Plant Diseases: Epidemics and Control. Academic Press, London.

155. Vavilov, N. I. 1997. Five Continents. International Plant Genetic Resources Institute, Rome. (Published originally in Russian in 1962)

156. Watling, R., Frankland, J. C., Ainsworth, A. M., Isaac, S., and Robinson, C. H., eds. 2002. Tropical Mycology: Vol. 1, Macromycetes. CABI Publishing, Wallingford, Oxon, UK.

157. Watling, R., Frankland, J. C., Ainsworth, A. M., Isaac, S., and Robinson, C. H., eds. 2002. Tropical Mycology: Vol. 2, Micromycetes. CABI Publishing, Wallingford, Oxon, UK.

158. Weiss, E. A. 2002. Spice Crops. CAB Interna- tional, Wallingford, Oxon, UK.

159. Wellman, F. L. 1967. Relative abundance of diseases on tropical crops. (Abstr.) Phytopathology 57:10.

160. Wellman, F. L. 1968. More diseases on crops in the tropics than in the temperate zone. Ceiba 14:17-28.

161. Wellman, F. L. 1972. Tropical American Plant Disease. The Scarecrow Press Inc., Metuchen, NJ.

162. Willig, M. R., Kaufman, D. M., and Stevens, R. D. 2003. Latitudinal gradients of biodiversity: Pattern, process, scale, and synthesis. Annu. Rev. Ecol. Evol. Syst. 34:273-309.

163. Yeh, S.-D., Gonsalves, D., Wang, H.-L., Namba, R., and Chiu, R.-J. 1988. Control of papaya ringspot virus by cross-protection. Plant Dis. 72:375-380.

164. Yirgou, D., and Bradbury, J. F. 1974. A note on bacterial wilt of banana caused by the enset wilt organism Xanthomonas musacearum. E. Afr. Agric. For. J. July issue pp. 111-114.

165. Zadoks, J. C., and Schein, R. D. 1979. Epidemiology and Plant Disease Management. Oxford University Press, Oxford, UK

166. Zentmyer, G. A. 1980. Phytophthora cinnamomi and the Diseases it Causes. Monogr. 10. American Phytopathological Society, St Paul, $\mathrm{MN}$ 